\title{
A HISTORY OF
}

THE BACTERIOLOGY DIVISION

OF THE CANADA DEPARTMENT

OF AGRICULTURE

1923/1955

A.G. Lochhead 
Digitized by the Internet Archive in 2012 with funding from

Agriculture and Agri-Food Canada - Agriculture et Agroalimentaire Canada 


\title{
A HISTORY OF THE BACTERIOLOGY DIVISION OF THE CANADA DEPARTMENT OF AGRICULTURE $1923-1955$
}

\author{
A. G. Lochhead \\ 1968 \\ Historical Series - Number 5
}

CANADA DEPARTMENT OF AGRICULTURE 
(c) Crown Copyrights reserved

Available by mail from the Queen's Printer, Ottawa, and at the following Canadian Government bookshops:

HALIFAX

1735 Barrington St.

MONTREAL

Aterna-Vie Building, 1182 St. Catherine St. West

OTTAWA

Daly Building, Corner Mackenzie and Rideau Streets

TORONTO

221 Yonge Street

WINNIPEG

Mall Center Building, 499 Portage Avenue

VANCOUVER

657 Granville Street

or through your bookseller

Price: $\$ 2.00 \quad$ Catalogue No. A54-2/5

Price subject to change without notice

Roger Duhamel, F.R.S.C.

Queen's Printer and Controller of Stationery

Ottawa, Canada

1968 
CONTENTS

Page

Origin, Function, and Path of Development $\ldots \ldots \ldots \ldots$

A Summary of Research Results.................... 17

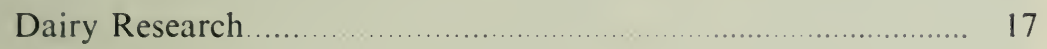

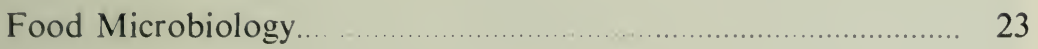

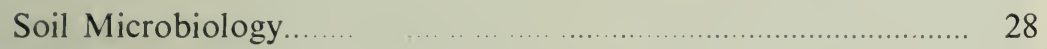

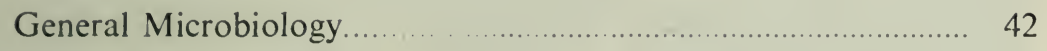

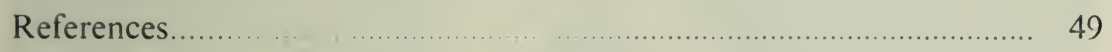

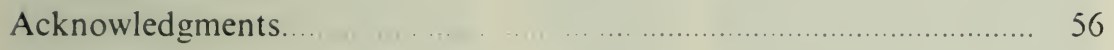




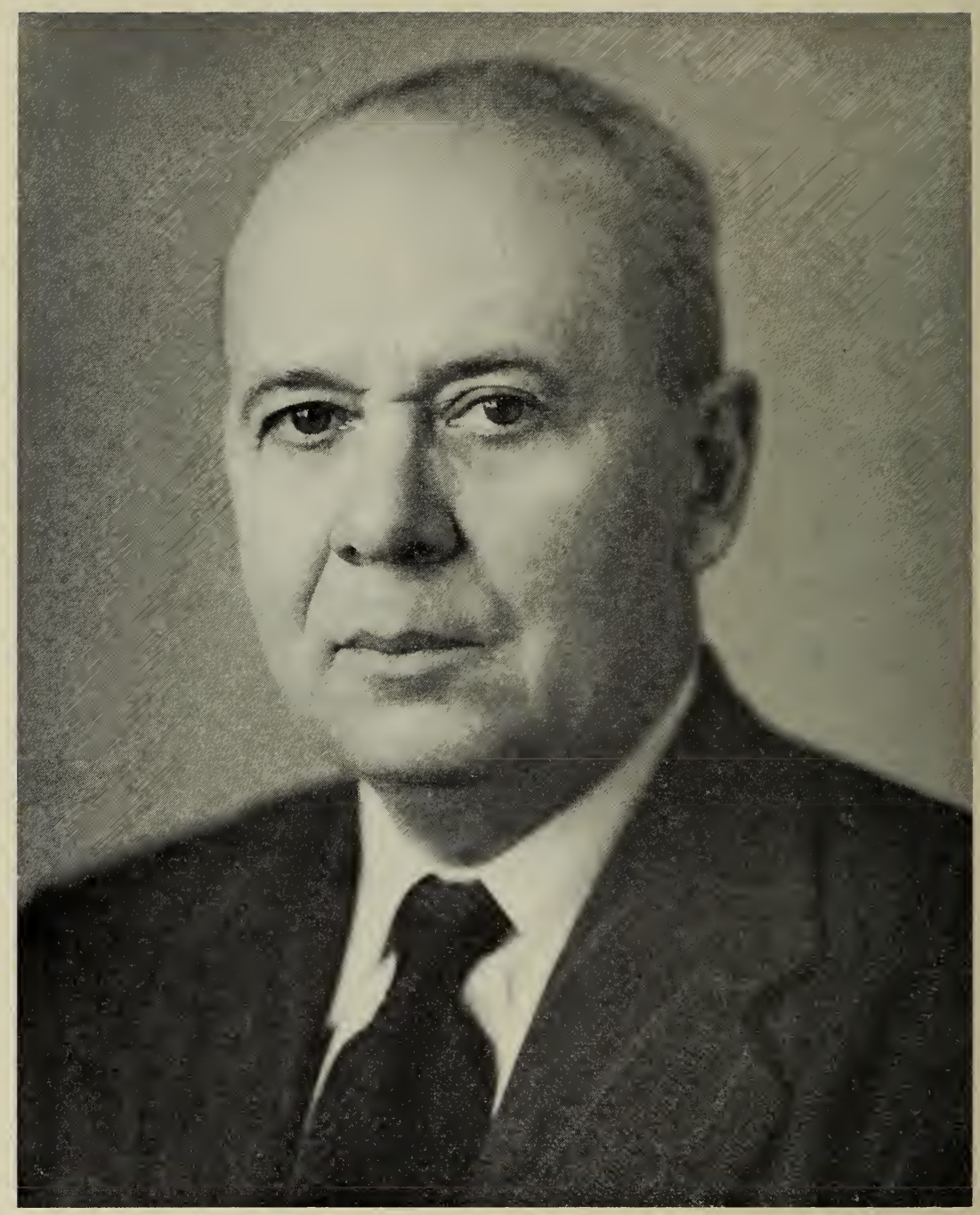

A.gkochlear 


\section{ORIGIN, FUNCTION, AND PATH OF DEVELOPMENT}

Bacteriological research in the Canada Department of Agriculture before 1923 was limited to problems of veterinary pathology related to the activities of what was known at that time as the Health of Animals Branch, as well as to certain aspects of the plant pathological work of the Botany Division of the Experimental Farms Branch. However, as the work of the Experimental Farms developed, it became increasingly apparent that many features of the experimental and research activities of the 12 divisions that comprised the Branch at that time required the cooperation of a bacteriological laboratory.

In recognition, therefore, of the direct bearing of many phases of agricultural practice, related to both animal and crop production, on the activities of microorganisms, the Bacteriology Division was created in 1923 as an integral part of the Experimental Farms Branch, then under the directorship of E. S. Archibald. On April 1, 1923, A. G. Lochhead assumed charge of the new division with the title of Dominion Agricultural Bacteriologist. The working quarters consisted of a single room, about 12 feet square, in the old Dairy Building. For three years this remained the sole accommodation available to the new division.

With the acquisition of a microscope and some of the more essential articles of bacteriological equipment, most of which would be regarded as quite inadequate now, when there is a preference for finished, preferably automatic devices rather than for simpler, even homemade contrivances, experimental work was begun in mid-1923. During the early years the size of the staff was commensurate with the space available. The single bacteriologist was assisted by a helper for 'washing up' and, somewhat later, by a graduate assistant, employed on an hourly basis, for benchwork. But inadequacies of staff, accommodation, and equipment seemed overshadowed by the realization that a start had been made.

Role of a Bacteriological Laboratory in the Experimental Farms System

Since the establishment of the Bacteriology Division came about because of the need for cooperative experimentation with the so-called 'productive' divisions of the Branch, it was natural and fitting that bacteriological work should develop as associative studies. On every side, numerous problems in farm practice were realized to have a bearing on the activities of bacteria and related microorganisms. In a soil supporting a crop of alfalfa, in a silo of corn, in a gallon of milk or a ripening cheese, in a colony of bees or a comb of honey, in a bin of stored vegetables, or in the water of a farm well, the quality of the 
product depends, at least partly, upon the presence and the activities, for good or bad, of microorganisms.

Although the role of bacteriology in a program of agricultural research may be regarded as analogous to that of chemistry, recognition of this was late in coming. Agricultural chemistry had much earlier beginnings. In the first half of the last century, when the first experimental station was founded at Rothamsted, England, a chemical laboratory was recognized as an indispensable part of an agricultural research establishment. This was at a time when bacteriology had not even begun to evolve as a scientific discipline in its own right. It was only during the last few decades of the nineteenth and the first decade of the twentieth century that discoveries in the younger science could be said to have justified its winning a place alongside chemistry to help solve many problems related to animal and crop production and to the utilization of agricultural products. The Chemistry Division had been an integral part of the Experimental Farms system from its inception in 1887 , and under the direction of F. T. Shutt it had already won a high reputation.

The newness of the younger branch of science was reflected in the paucity of workers in all branches of bacteriology in 1923. At that time agricultural and industrial bacteriology were represented in Canada by perhaps a dozen workers, most of whom were attached to three colleges where separate, though small, bacteriology departments had been organized and courses offered. These were the Ontario Agricultural College, Macdonald College, and the Manitoba Agricultural College. All the investigational work that applied to agriculture was confined to these institutions. The development of bacteriology in industry, which has been prominent in the fields of food preservation, fermentation, pharmaceutical production, and many others, is largely a phenomenon of the past two or three decades. In 1923 the few workers in bacteriology were mainly concerned with essentially routine problems of quality control in the dairy industry.

In laboratories of federal government departments, very small staffs were engaged, before 1923 , in work connected with public health and hygiene or veterinary medicine. In recent years growth in these fields has been outstanding. In other fields, too, federal support, notably through the National Research Council and the Fisheries Research Board, has led to the establishment of bacteriological laboratories where work is devoted to problems of industry that are related to many facets of the Canadian productive economy.

As a result of federal support and development and concomitant expansion of bacteriological work on a provincial level, as well as in the universities, the application of bacteriology has been greatly fos- 
tered and the number of research workers has increased proportionately. However, the establishment of the Bacteriology Division by the Department of Agriculture marked the inauguration of the first government-sponsored project for general or agricultural bacteriological research in Canada.

\section{Type and Scope of Work Inaugurated}

Just before his arrival to take up his duties, the chicf of the new division received from the Director of Experimental Farms a memorandum "outlining a few lines of bacteriological investigations" in which cooperation was requested by 10 of the Experimental Farms divisions. There were 22 of them, covering a wide range of topics, related to ficlds such as dairying, soil fertility, fiber retting, apiculture, and food storage. So assurance was given that the activities of the new bacteriological laboratory would be lacking in neither interest nor variety.

In spite of the number and the attractiveness of the projects with which the laboratory was confronted, the staff started work with the conviction that a small number of projects was to be preferred to a large number, and that a laboratory with limited staff and facilities working on a small list of projects would produce more of lasting value than one of equal size whose energies were dissipated over too wide a list of undertakings. Because of the small staff, a limitation of projects was imperative.

The question early arose as to the balance to be struck between the aspects of research that are called applied and fundamental. Much has been written on the nature of, and the differences between, applied research, which attempts to apply scientific findings to the solution of practical problems, and fundamental, or pure research, which attempts to establish scientific facts and relationships as such and so increase the fund of knowledge which may or may not, but usually does, become available for practical use. Though there is no clear line of demarcation between these two aspects of research, certain projects may, by their nature, be readily classified as applied, whereas others may be regarded as fundamental because the point of application, particularly at the outset, may be quite obscure.

In establishing a general policy for the direction research was to take in the new division it was early realized that the two kinds of research were complementary. It was felt that in the best interests of the industry it was hoped to serve, close contact was essential between the experimentalist and the 'pure' scientist, and that with any weakening of such a bond the tendency would be for applied work to languish and for pure research to lose direction. 
In the development of a program of research and experimentation, it was necessary to keep in mind, too, that if the laboratory was to fulfill the functions for which it was established, operations of a 'service' nature had to be maintained. This work, for the most part routine in nature, consisted in providing to other divisions of the Experimental Farms, to other branches of the Department, and to the farming community in general an analytical service for examining samples requiring bacteriological testing. In many instances the examination of samples was far from routine in nature, and called for fresh methods of approach to be devised. Not infrequently, what at first seemed a simple analytical study led to significant findings and developed into a full-fledged research project.

For the first 14 years the 'service' or 'extension' work of the Division included the preparation and distribution of cultures for the inoculation of legume seed (so-called 'nitro-cultures') on a free, though limited, basis to farmers across the country. This service, which assumed large proportions in the spring, caused a serious seasonal curtailment of research activities while the staff remained small. However, by providing farmers with an opportunity to test the value of inoculation, it made a valuable contribution to successful legume cultivation until cultures could be produced commercially in Canada.

In addition to its 'non-official' analytical service, the Division was called upon to conduct analyses on products for which standards of quality were set under various acts and regulations administered by the Department of Agriculture. These consisted mainly of food products, and, over the years, as more and more products came within the scope of such regulatory activities, the number of 'official' samples increased proportionately. The Division took a leading part in devising microbiological standards for various products, and this necessitated much study and consultation with the branches administering the regulations as well as with the industry itself.

\section{Path of Development 1923-1955}

During the years immediately following the creation of the Division in April 1923, growth of both staff and facilities was slow. From the single room in the Dairy Building the headquarters was moved in 1926 to a small wing of the Cereal Building, which had been vacated when the Botany Division moved to the Arboretum. Although the quarters in the Cereal Building, which were occupied for 23 years, permitted some extension of work, the facilities were hardly adequate for appropriate expansion of effort. They consisted of three laboratories (two quite small and none well suited to maintenance of aseptic 
surroundings) without separate preparation rooms and, in addition, a small room that served as the office for the Chief, the Senior Assistant, and the stenographer, and also as the divisional library.

The first addition to the scientific staff of the Division was made in September 1927, when C. K. Johns, later Director of the Dairy Technology Research Institute, was appointed Assistant Agricultural Bacteriologist, and he assumed immediate charge of the dairy bacteriological work. At the same time, J. C. Petitclere was appointed Laboratory Assistant; he was replaced in 1930 by N. B. McMaster. In that year Miss L. N. Farrell joined the staff as a temporary appointec of the National Research Council to cooperate in research on honey fermentation, a project that received support in this way from NRC because they were without a microbiological laboratory then.

Up to 1930 research work was confined largely to the fields of dairy and soil microbiology. Although these subjects continued to be the chicf areas of investigation, increasing attention was gradually devoted also-as far as facilities and staff permitted-to other projects, diversified in nature but representing problems in which assistance was requested. Thus, by 1934 work had been inaugurated on such projects as honcy spoilage, foulbrood diseases of bees, bacterial discoloration of salted hides (brought to our attention by the National Research Council), and methods for detecting contamination of water (in cooperation with the Canadian Public Health Association).

The same year, 1934, marked the beginning of continuous work in food microbiology, which developed to constitute, with dairy and soil work, the third major section of investigational work in the Division. By 1936 the technical staff comprised six members; in addition to the divisional chief these were C. K. Johns (dairying), R. H. Thexton and C. B. Taylor (soils), A. H. Jones (foods), and G. B. Landerkin (general).

In December 1923, a Division of Dairy Research had been established by the Department as part of the former Dairy and Cold Storage Branch under the then Dominion Dairy Commissioner, J. A. Ruddick. E. G. Hood was appointed as Chief of the newly created division and was joined in 1924 by A. H. White and, in 1925, by H. L. Bérard, who subsequently became Director of the Quebec Provincial Dairy School at St. Hyacinthe. Located in downtown Ottawa, this division directed its attention to problems of manufactured dairy products -butter, cheese, dried milks, and ice cream. Though the work on milk production problems carried out at the Central Experimental Farm by the Bacteriology Division complemented that of the Division of Dairy Research, the activities were difficult to coordinate, particularly as the latter division was operating under the disadvantage of being 
without facilities for experimental dairy processing. This anomalous situation was corrected following reorganization of the Department of Agriculture in 1938 when both divisions were brought within the newly created Science Service under the directorship of J. M. Swaine and amalgamated as a single division, known as Bacteriology and Dairy Research.

In 1939 the staff of the former Division of Dairy Research moved to the Central Experimental Farm to occupy new laboratories in the old Dairy Building. This move, by permitting an integration of dairy research activities at one location, greatly strengthened the work in dairying, as well as that of the Division as a whole, and though work was still hampered by the inadequate processing facilities available at the time, this lack was finally remedied by the provision of a new building in 1953 .

Following the move from downtown Ottawa, E. G. Hood was placed in charge of dairy research, where he remained until his death in 1953. During this period Dr. Hood's own work was concerned mainly with problems of Cheddar cheese, particularly deterioration due to rancidity, while $\mathrm{A}$. $\mathrm{H}$. White dealt more with factors affecting quality in butter and dried milk. Throughout the investigations carried out by this section cooperation was maintained with the Chemistry Division through I. Hlynka, with the Animal Husbandry Division through C. A. Gibson, as well as with the University of Alberta through H. F. Thornton and H. Wolochow in studies on butter flavor. In 1939 C. K. Johns assumed charge of the greatly expanding work in food microbiology, which developed particularly during the war, maintaining in addition his investigation of problems of milk production and the development of methods for assessing milk quality. In this work he was ably assisted by R. K. Howson who, early in the war (1940), was killed while on active duty with the RCAF.

Dr. Johns succeeded Dr. Hood in directing the newly designated Dairy Technology Research Unit, which included not only a bacteriology section, directly under his guidance, but a chemistry section attached to the Chemistry Division of Science Service as well as a processing section under the Animal Husbandry Division of the Experimental Farms Service. At the same time the name of the Division of Bacteriology and Dairy Research reverted to the Bacteriology Division, a more logical designation in view of the involvement of other sciences in dairy research. This dairy research setup remained in force until April 1959, when, with the reorganization of the Department, all dairy research was coordinated within the Dairy Technology Research Institute. 
Research in food microbiology, which began in 1934 as a cooperative investigation with the Horticulture Division on the subject of frozen-pack vegetables and fruits, developed greatly in the years before and during the war. The same year marked the beginning of studies in cooperation with the Poultry Division, the Livestock Branch, and the National Research Council on the preservation of dressed poultry; and cooperation with the NRC and the meat-packing industry on the bacteriological aspects of the curing of Wiltshire bacon, which was then, as well as during the war, an important export product to the British market. In this latter project E. H. Garrard, now Head of the Department of Microbiology, University of Guelph, was actively engaged during 1937-1938 while attached to the Division as an exchange worker.

After the outbreak of war, food microbiology, as might have been expected, received special emphasis, particularly with respect to efforts to maintain the quality of products destined for overseas shipment. To help most effectively in the war emergency it was necessary to shift emphasis on the project work of the Division. Consequently, through an extension of cooperative effort with the Production and Marketing Services of the Department, and indeed the food-packing industry at large, much attention was given to the very practical problems of the maintenance of quality of a variety of foodstuffs of critical importance. Dr. Johns was placed in charge of food microbiology in 1939. To provide improved facilities for work related to fruit and vegetable processing, a bacteriological laboratory was equipped in the Horticulture Building. When these quarters were occupied in 1944, with A. H. Jones in charge of this section of the work, more effective liaison between practical processing and bacteriological research was possible. The same year, the establishment of a bacteriological laboratory at the Experimental Station, Summerland, B.C., provided cooperation in fruit- and vegetable-processing problems in Western Canada. C. O. Gitterman was placed in charge of this work. He was succeeded by Miss M. O. Burton, who joined the Ottawa staff of the Division in 1948 when J. F. Bowen, then in Ottawa, assumed charge of the branch laboratory.

Coincident with the expansion of investigational work in dairy and food microbiology was the development of soil microbiological research in the Division. As the youngest branch of soil science, soil microbiology was in 1923, and still is, the least explored field. It has, however, given rise to the concept of soil as a living thing, a concept which has been changing our view of soils, and one that must be constantly kept in mind in contemporary soil research. As soil was recognized as the most complex natural medium from a microbiological point of vicw, it 
seemed obvious at the outset that a program of fundamental research was needed if any eventual application to soil science as a whole and to our many-sided agronomic problems was to result. The Division has striven to play a leading part in soil research in Canada, and there have emerged indications that investigational work in a field where there are no quick answers to be found, and where research findings are much less readily or obviously adaptable than, say, in dairy or food technology, has yielded results with promise of application to practical soil problems.

Though certain aspects of soil microbiological work were rightly directed towards more immediate practical ends-for example, cooperative studies on seed inoculation problems with various Branch Experimental Farms in areas where certain legumes, such as alfalfa, were being grown for the first time-fundamental studies have been promoted throughout the course of the Division's history. The accumulation of basic knowledge of the ecology and physiology on the various groups of soil microorganisms was considered important to a better understanding of the part soil microbes play, not only as regards soil fertility as such, but in relation to the incidence and control of soilborne diseases of crops.

Before 1936 soil microbiological studies had been worked on by the Chief of the Division with the help of R. H. Thexton. In that year the staff was strengthened by the addition of C. B. Taylor and in 1937 by M. I. Timonin, which brought to seven the number of scientists on the roll. These men had been trained in two of the outstanding schools of soil microbiology, Rothamsted and New Jersey respectively. Dr. Taylor returned to England in 1938 and was replaced by P. M. West, trained in the Wisconsin school, while Dr. Timonin remained as an active member of the staff until 1952.

In 1939 the first laboratory of the Division outside of Ottawa was established. Under a plan promoted by the Director of Science Service, J. M. Swaine, space was provided at the Dominion Laboratory of Plant Pathology at St. Catharines, Ontario, to inaugurate research on soil microbiological aspects of soil-borne diseases. P. M. West was assigned to cooperate with plant pathologists under the general direction of $\mathrm{G}$. H. Berkeley, Officer-in-Charge of that laboratory. An auspicious start was made in this cooperative venture, which was maintained until the reorganization of the Department. Strawberry root rot, and later tomato root rot and potato scab were the main subjects of study, to which A. A. Hildebrand, L. T. Richardson, and R. G. Atkinson contributed as plant pathologists. Dr. West was succeeded in 1941 by H. Katznelson, later Director of the Microbiology Research Institute, who had joined the staff of the Division, at Ottawa, the previous year. He returned to 
Ottawa in 1943 when this outside work was temporarily halted to permit the assignment of staff to certain projects connected with the war effort. Following the war, work at St. Catharines was resumed in 1946 with J. W. Rouatt as bacteriologist, and in 1949 J. B. Robinson succeeded him as divisional representative.

A second extension of cooperative work on problems of plant pathology related to soil microbiology was made in 1951, when a bacteriologist was assigned to the Dominion Laboratory of Plant Pathology at Saskatoon. The prime object was to assist in problems of common root rot of wheat to which that laboratory had made notable contributions under the general direction of P. M. Simmonds, Officerin-Charge. With the appointment of S. H. F. Chinn, a program of research was inaugurated with the collaboration of plant pathologists, notably R. J. Ledingham and B. J. Sallans, and it has been steadily maintained.

Although during the war the attention of the soil microbiology section of the Division was partially diverted to more immediate wartime projects, continuous, though somewhat curtailed, research was maintained throughout that time and later strengthened. Special emphasis was directed towards the qualitative study of soil microorganisms and to the relationships between soil microorganisms and growing plants (rhizosphere studies). Besides the members of the staff already mentioned who were active during this period, contributions to progress were made during the war and subsequently by J. J. R. Campbell, now Head of the Department of Microbiology, University of British Columbia, F. E. Chase, who was on our staff from 1941 to 1944, and I. L. Stevenson and E. A. Peterson, who joined in 1951 and 1953 respectively. From 1953 until 1959, when he left because he was appointed Professor of Bacteriology at the University of Manitoba, the late T. M. B. Payne was a valued member of the staff.

Problems relating to agricultural production or the utilization of agricultural products that bear on the science of bacteriology do not all fall squarely within the fields of dairying, food preservation, or soil research. Consequently, from the very first, many miscellaneous investigations were undertaken that arose largely out of matters brought to our attention by other divisions of the Experimental Farms, other branches of the Department, or outside agencies. Many such investigations arising from efforts to assist in practical problems developed into research projects of a more basic nature as the course of the studies revealed aspects of microbiology that required a more fundamental approach. 
Considerable study was made on diseases of bees, especially the foulbrood diseases. This work had been initiated in 1925 and continued, as far as resources of personnel would permit, throughout the period under review. Such investigations combined the practical aspects of the problem, directed towards control measures and the development of diagnostic procedures, with research on the physiology of the organisms involved in disease. The later phases of the work, after 1944, were undertaken mainly by $\mathrm{H}$. Katznelson, who combined these studies with his other work in soil microbiology and on certain wartime projects. Other investigations of a special nature were concerned with fundamental studies on halophilic (salt-loving) bacteria, particularly their classification and physiology, which arose from work on red discoloration of salted products and on meat curing.

During the war, cooperative studies were carried out with the National Research Council on various aspects of the production of 2,3-butanediol by a fermentation process involving the use of lowgrade wheat or other sources of starch. The purpose of the work was to study the feasibility of the microbiological process as a first step in the production of synthetic rubber. This project, which lasted three years under Dr. Katznelson, was concerned with special features of the fermentative activity of Bacillus polymyxa. During the same period studies were made of the production of antibiotics, chiefly citrinin and clavacin, certain aspects of which were carried out jointly with Macdonald College. Postwar studies on antibiotics dealt with surveys for antibiotic-producing actinomycetes in soil. Members of the staff chiefly concerned with antibiotic studies were M. I. Timonin, F. E. Chase, and G. B. Landerkin.

Because of the increased attention devoted to special aspects of microbiology, and in realization of the importance of furthering research related to microbial physiology, Dr. Katznelson was placed in charge of a section on General Microbiology in 1950. This work was expanded in an important direction through cooperative studies with the Botany and Plant Pathology Division on certain seed-borne bacterial plant pathogens causing blights. Of special significance was the application of bacteriophages for the rapid diagnosis of the presence of the pathogen. At the same time the increasing application to microbiology of biochemical procedures led to the inauguration of research related to general metabolism as well as to studies on the metabolic pathways characteristic of the physiology of bacteria of agricultural importance.

Following the appointment of the late K. W. Neatby as Director of Science Service in 1946, first steps were taken to arrange for the 
accommodation of the headquarters and main laboratories of the Division, with certain other sections of Science Service, in the Government Records Building taken over by the Department of Agriculture. This building became known first as the Science Service Building and later, following the more recent addition to the structure, as the K. W. Neatby Building. The new laboratories were ready for occupation in December 1949, and for the first time since its establishment in 1923 the Division was able to operate with space and facilities adequate to its requirements. Owing to the necessity of maintaining the closest cooperation of the dairy and food bacteriology units with the Animal Husbandry and Horticulture Divisions of the Experimental Farms, these sections of the Division continued to occupy their respective quarters in the Dairy and Horticulture Buildings. It is of interest to recall that at the time of this move the total establishment of the Division, including the staff at outside laboratories, was 30, of which 14 comprised scientific personnel. During the years 1950 to 1955 , the end of the period here under review, development continued, broadening the research program in line with the 'changing face' of microbiology, with concomitant additions to the staff in Ottawa and, to a lesser degree, outside. In 1955 the personnel total stood at 48, 39 at Ottawa and 9 outside; the total scientific staff being 22. Besides the extension of activities outside Ottawa already referred to, namely at St. Catharines, Summerland, and Saskatoon, two bacteriologists were assigned to the newly established Science Service Laboratory at London, Ontario, in 1951. However, unlike the situation at the other branch laboratories, attachment to the Division in this case was only nominal, since the work in question was coordinated with the autonomous program of research in that institution under the direction of $\mathrm{H}$. Martin.

The increased staff available for research during the 1950's permitted, for soil microbiology, not only an extension of work begun earlier on such topics as the relationship of soil microorganisms to plants and to soil-borne diseases of crops, but also to various aspects of the ecology and physiology of soil bacteria and related microorganisms. Among these were investigations of amino acids, vitamins, and other growth factors in soil which dealt with their origin, their importance in the nutrition of microorganisms, and their synthesis by soil microbes, work in which Miss M. O. Burton was actively engaged as well as the workers in soil microbiology mentioned above. Dairy bacteriology also developed along some new paths; for example, a study was made of the effect on dairy products and dairy processing resulting from the greatly increased use of antibiotics for treating cattle diseases. Work on the action of disinfectants, earlier studies of which were directed mainly to their application as sanitizers in dairying and in 
food processing under C. K. Johns, later with T. W. Humphreys, developed along more fundamental lines with C. E. Chaplin, who studied, in particular, the mechanism of germicidal action and the development of resistance by bacteria.

From 1950 to 1955 the staff and facilities permitted the beginning of new approaches in line with the directions that modern microbiology had taken. Even with a constant awareness, during the course of the development of the Division, that work was justified in proportion to the degree to which it could serve Canadian agriculture, it became increasingly apparent with the years that with such a practical goal more and more emphasis had to be laid on fundamentals. Consequently, starts were made, or work furthered, on such topics as bacterial cytology, bacterial genetics, and bacterial biochemistry, to find out more about how and why microbes behave as they do. Though such aspects of research have since been strongly fostered in the Microbiology Research Institute, studies in the Division, particularly by H. Katznelson, C. E. Chaplin, and J. Robinson, showed the value of including these new directions in the general work program. It has been aptly said that "biochemists have now discovered bacteria and the bacteriologists have discovered genetics." However that may be, biochemistry, which for several decades has been but a handmaiden of microbiology, is now a full-fledged partner. Along with genetics and the newer cytology, it is playing an essential role in helping microbiology to serve agriculture.

The staff of the Bacteriology Division of the Canada Department of Agriculture in 1955.

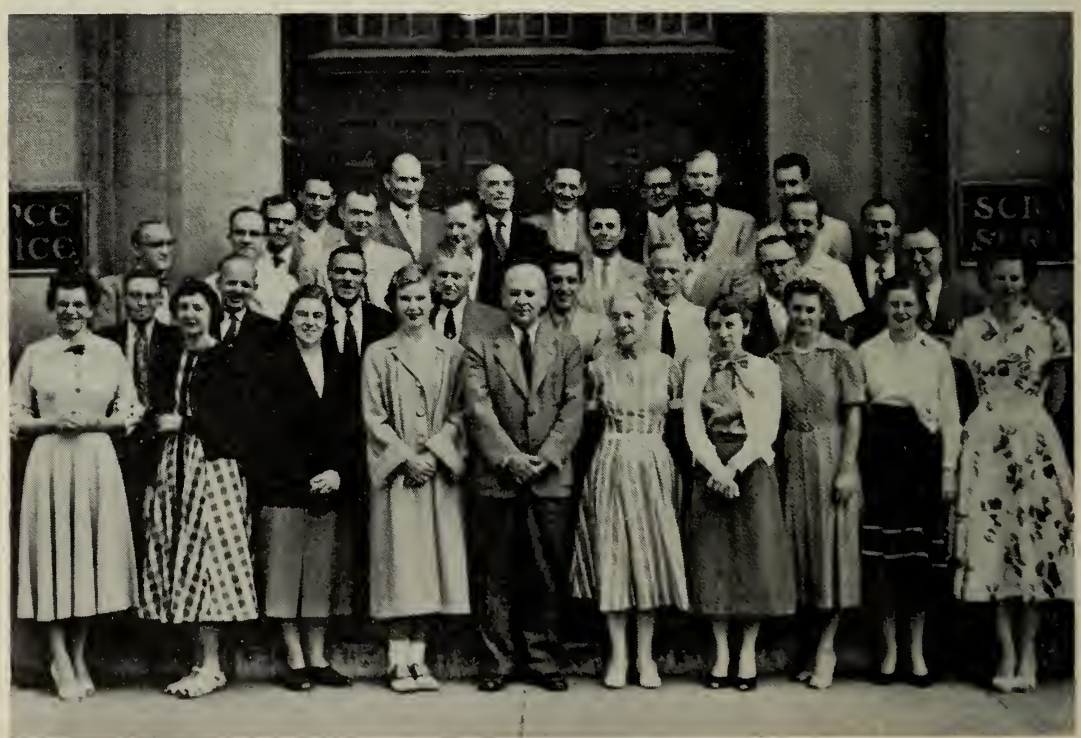




\section{A SUMMARY OF RESEARCH RESULTS}

In the diverse fields of study the work of the Division embraced, as suggested in the previous section of this review, not only research, which varied from the basic to the applied, but also experimentation related to the practical aspects of quality control. In consequence of this diversification of work in which projects varied from minor to major, though not necessarily in scientific approach or methodology, it is not intended to present an all-inclusive summary of research but rather to indicate some of the more important findings in certain areas of investigation. ${ }^{1}$

\section{DAIRY RESEARCH}

Milk

It is now a truism that the production of clean milk is of the utmost importance to the whole of the dairy industry inasmuch as the quality, not only of fluid milk but also of manufactured dairy products, is dependent upon the quality of the raw supply. In the 1920's measures now considered necessary, indeed obvious, for ensuring a high quality of milk were not as generally known. Consequently a program of investigation was inaugurated that embraced studies of methods for producing and maintaining milk of high sanitary quality, with essential concomitant studies of methods for assessing quality. If any justification for such work was needed, it could be found in the excessively high contamination generally prevalent in the milk being produced at that time in most parts of the country.

The first investigation undertaken by the Division, with the active cooperation of the Animal Husbandry Division, was aimed at studying the sources contributing to the contamination of milk produced under commercial conditions. It was particularly important to distinguish between the chief sources of contamination and others of lesser importance. In a half-year study, in which the worst possible methods of production and conditions in stables were improved step by step until optimum conditions were attained, it was clearly shown that the producer and the methods he employs are far more significant than the barn and equipment he possesses. By the use of proper methods 99 percent of the bacterial contamination occurring where careless, unsanitary conditions prevailed could be eliminated. It was clearly demonstrated that milk of high sanitary quality can be produced in simple surroundings by the exercise of simple precautions, once the chicf sources of

${ }^{1}$ Although no attempt is made to list all the 374 publications of the staff of the Division during the period reviwed, the more significant references to the topics discussed are given. 
contamination are understood. These are: a clean animal, a clean, sterilized pail and, in the case of hand-drawn milk, a covered pail. Care taken to prevent contamination from the many minor sources is largely wasted unless, at the same time, contamination from the chief sources is also prevented. The first bulletin issued by the Division (60) dealt with this subject.

A closely related subject was the role of the milking machine, then coming into more general use, in the bacterial contamination of milk. At the time there was much conflict of opinion among dairymen concerning the ability of the machine to produce milk of low bacterial content that would be comparable with the product of good hand milking. The study on the degree of milk contamination and on the incidence in the milk of bacteria of various types was made from 1926 to 1928 in a series of detailed experiments, set up to examine the effect of many variations in handling, cleaning, and sterilizing the machine and its connections (77).

The findings showed the sanitary condition of the rubber parts of the milking machine to be the chief factor affecting the bacterial content of machine-drawn milk. Factors associated with the handling of the machine assume importance only when the rubber parts have been adequately washed and some method of positive 'sterilization' applied. Treatments by steam, hot water, and chemical solutions were found satisfactory for maintaining the tubes in sanitary condition, though heat methods had a more deleterious effect upon the rubber parts than the equally effective chemical treatment. Subsequent studies to compare the efficacy of different chemical treatments showed that, although the chlorine compounds were effective in controlling contamination, a weak solution of lye had the added advantage of destroying coliform bacteria to a much greater degree. The latter had, furthermore, the advantage of low cost. It was therefore possible to recommend lye treatment to milk producers as the most effective and economical procedure for controlling contamination with milking machines (19). This procedure has been widely adopted, and although newer detergent-sanitizers later showed considerable promise none tested by the Division was found to surpass the lye treatment.

Equally as important as the ability to produce clean milk is the ability to recognize it; that is to say, methods for assessing the sanitary quality of milk, or indeed of any food product, are essential to progress. The three main types of tests, based on cultural (plating) procedures, direct microscopic observation, and dye color reduction respectively, are, to a certain degree, complementary, for no one method furnishes all the information needed for complete quality control. Furthermore, modifications in procedures, as well as standards, are war- 
ranted from time to time as milk quality improves. Chief ansong the contributions of the Division to procedures were important modifications of the dye reduction tests used for measuring the quality of raw milk. A thorough study of the factors influencing the methylene blue reduction test led to a modification involving a preliminary incubation of the milk. This yielded a method that provided a better measure than before of the keeping quality of milk. Of special significance was the development of the triple reading resazurin test (31), which was widely adopted in Canada and which, since 1948, has been recognized by the American Public Health Association as a standard method for the examination of milk.

Butter

Research was directed principally towards improvement in the quality and keeping characteristics of commercial butter through studies of the causes underlying the development of defects-relating chiefly to flavor and color-and the development of remedial measures to be taken for their prevention and control.

In cooperation with the University of Alberta, a concerted attack was made on the butter defect known in this country as 'surface taint,' which occurred sporadically-more during warm than cold seasonsand particularly in Western Canada, causing serious loss to creamery operators. Characterized by a very obnoxious odor capable of rapid development, the taint was found to be caused by either Pseudomonas putrefaciens or another type of bacterium found during the course of the work and named Flavobacterium maloloris. Both of these organisms are water-borne. Following extensive studies in the laboratory as well as in creameries where the defect had occurred, control measures that greatly reduced the incidence of the defect could be recommended. These measures involved treatment of water supplies combined with a rigorous program of general plant sanitation (116).

Laboratory studies combined with plant investigations also resulted in determining the cause of, and in recommending control measures for, a defect of butter known as 'surface discoloration,' which caused loss to butter handlers and retailers. The defect was encountered chiefly in the Prairie Provinces and Ontario. Though not ordinarily observable on butter coming from cold storage, it appeared as bluish-black areas on the surface of print butter of low salt concentration held at temperatures between $40^{\circ}$ and $60^{\circ} \mathrm{F}$. After detailed study of its characteristics, the defect was found to be caused by the growth of a pigment-producing organism that was named Pseudomonas nigrifaciens. Practical control measures included careful pasteurization, salting butter to at least 1.25 percent, dry wrapping to minimize extraneous moisture, and 
maintenance of thorough sanitation of plant and equipment to prevent any recontamination of finished butter (114).

The role of microorganisms in certain other defects of butter is not so clearly established; indeed they may contribute only to an insignificant degree, and yield to chemical and enzymic factors. Fundamental studies were undertaken on storage butters to determine the causes of such defects, which are chiefly confined to butter surfaces and are referred to by graders as tallowy, stale, metallic, oxidized, fishy, or otherwise. It was found, for instance, that one of the most important factors in surface deterioration is acidity, and the need for careful neutralization was clearly established. It was concluded that if such surface defects are to be kept under control, care is necessary, not only to prevent microbial contamination, but also to have the butter at optimum $\mathrm{pH}$ values, 6.7 to 6.9 , and to keep metallic contamination, particularly by copper and iron, at a minimum. Since air and light induce such off-flavors, prompt cold storage was shown to be necessary to retard chemical changes in butter constituents, particularly fats (115).

Closely associated with the occurrence and the control of flavor and color defects in stored as well as print butter, are faults of packing and wrapping. Many such faults, previously prevalent in the industry, are now encountered rarely owing to practical remedies worked out and recommended by the Division following laboratory and plant studies conducted in collaboration with butter manufacturers. Among such measures to offset defects may be mentioned the use of the casein-formalin treatment for butter boxes, the double parchment liner, and aluminum foil wrap.

\section{Cheese}

Rancid flavor in Cheddar cheese was a defect that had plagued the industry for many years. The earliest studies had suggested that the defect was caused by lipolytic bacteria in the milk being capable of decomposing milk fat through the action of the enzyme lipase, and so of producing sufficient quantities of butyric acid during the manufacture and ripening of the cheese to induce the characteristic rancid flavor. Though bacteria are undoubtedly involved, early work in the Division showed the matter to be more complex than at first believed, biochemically as well as bacteriologically. Consequently a concerted attack was made on the problem with the cooperation of the Chemistry Division, the Animal Husbandry Division, and the grading staff of the Department.

As a result of the research carried out over several years, it was concluded that several interrelated factors were involved in the devel- 
opment of rancidity. Although single factors could produce the defect in varying degree in experimental cheese, it was considered that an interplay of factors determined the degree of rancidity in cheese made under commercial conditions. The findings stressed the significance of milk lipase, as distinct from bacterial lipase, as an important contributing factor. Milk lipase action could be greatly increased by the agitation of uncooled cheese milk. This could be attributed to the greater dispersion of the fat globules, resulting in an increase in the area of the fat-aqueous interface in agitated milk with consequent greater hydrolytic decomposition of butter fat $(14,15)$. Heavy contamination of cheese milk with lipolytic bacteria was shown to be a contributing factor, while the defect was lessened by such circumstances as a rapid rate of acid development during cheesemaking and by kecping milk destined for cheese at lower temperatures than other milk.

Other significant contributions to cheesemaking included a study of starter failure in certain factories in eastern Ontario, where it was believed to have been encountered for the first time in North America (32). This was found to be caused by the action of a polyvalent streptococcal bacteriophage, which prevented normal acid development and resulted in a lowering of cheese quality. The work showed the need for substituting a starter of different bacterial strains, and for thorough plant sanitation, to eliminate the trouble.

A further impediment to proper starter action arose with the use of antibiotics, such as penicillin, for the treatment of bovine mastitis. Where only occasional infected animals are treated there is little problem, owing to dilution of the antibiotic in the pooled milk supply; however, with extensive use of antibiotics sufficient amounts may be carried into the milk to inhibit development of the lactic streptococci. Comparative studies with six antibiotics showed the concentrations at which growth of many strains of lactic acid bacteria were inhibited. Penicillin was the most inhibitory of those tested (42). Later studies showed that factory starters from various cheesemaking areas varied considerably in their sensitivity to antibiotics (24). In practice the effect of antibiotics could be avoided by withholding milk from cheesemaking immediately after animals had been given antibiotic treatment, or, in the case of penicillin, by the use of penicillinase.

Help was extended to the industry through the investigation of a new type of spoilage that appeared in 1948 in Canadian process cheese and involved considerable financial loss. Defective cheese was badly swelled with gas, had a most disagreeable odor, and was quite inedible. The responsible organisms could be identified as Clostridium sporogenes or the closely related Clostridium pasteurianum, development of which was favored, under experimental conditions, by the use 
of skim milk powder. Salt level and $\mathrm{pH}$ were found to be the major factors inhibiting spoilage, and a salt concentration of 4 percent in conjunction with a $\mathrm{pH}$ value of approximately 5.2 could be recommended to the industry for effective control $(16,18)$.

A storage defect in Cheddar cheese, known as rind rod or wet end, which threatened to assume serious proportions, made a study of the causative agent and appropriate control matters of economic importance. Microbiological and chemical investigation showed that the defect was related to the presence of excess moisture at the top and bottom of the cheese, caused by improper temperature and humidity control during curing, faulty rind formation, the use of unseasoned wood for boxing, and the locking in of excessive surface moisture at the time of paraffining. Molds that contaminate the surface, chiefly species of Penicillium, Aspergillus, and Monilia, as well as yeasts and actinomycetes, promoted proteolysis of the outer layers under excessive moisture conditions and development of the rind rot (17).

\section{Mastitis}

Work carried out by the Division on the control of chronic contagious mastitis in the Experimental Farm dairy herd led to studies of certain aspects of the detection of this disease and of the effect of mastitis milk on cheesemaking. Investigation of the relationship between the presence of infection by Streptococcus agalactiae, and values of chlorides, $\mathrm{pH}$, and catalase, widely used as indirect biochemical tests for mastitis, revealed that in many cases abnormal values were found where no evidence of infection could be noted. It was shown that reactions to these tests may fluctuate widely from milking to milking for both infected and noninfected quarters. The findings pointed to the need for caution in applying biochemical tests for diagnosing mastitis infection and emphasized the need for examining a series of samples at consecutive milkings to obtain a reliable picture of the condition of a quarter. Of the tests studied, the catalase test was shown to be the most sensitive indicator of infection (29).

In cooperation with the Animal Husbandry, Chemistry and Dairy Products Divisions, experiments were made to note the effect of 'mastitis' milk on the yield and quality of Cheddar cheese. Milk considered abnormal on the basis of the biochemical tests alone, as well as milk having a latent infection with $S$. agalactiae, gave lower yields of cheese than normal milk, due to a lower content of solids-notfat (30). Subsequent experiments with factory milk showed that the quality of the cheese, which was slightly lower at initial grading than cheese from normal milk, declined more rapidly during ripening. 


\section{FOOD MICROBIOLOGY}

As with dairy microbiology, much of the research dealing with foodstuffs was understandably carried out in close cooperation with industry to help to solve practical problems. This was particularly the case with newly developing industries, such as those concerned with freezing and dehydration, which came into prominence during the period under review. In most instances research was inaugurated in response to requests for cooperation from various other divisions of the Department whose work was closely concerned with the production and marketing of the food products in question.

In food preservation, safety, from a public health standpoint, is obviously of prime importance, and Canadian food enjoys a good reputation in this respect. However, quality, as distinct from safety, is a major consideration in the acceptability, the keeping quality, and the grade of food, and consequently in the financial return, not only to the packer and distributor, but to the producer as well.

\section{Fruits and Vegetables (Frozen)}

Studies on the bacteriological aspects of the preservation of fruits and vegetables by freezing were initiated in 1934 with the Horticulture Division, which took a leading part in pioneering the development of this industry in Canada and in establishing it on a sound basis. In this work constant liaison was maintained with the Fruit and Vegetable Division, Marketing Service.

It was found that at freezing temperatures there was a pronounced decrease in the numbers of microorganisms occurring in freshly packed vegetables during the first week, and afterwards the numbers declined slowly or remained stationary. With fruits the decline was more gradual but more prolonged. With vegetables the microbial load was much higher than with fruits; and whereas bacteria were by far the most predominant organisms on vegetables, both when freshly packed and after prolonged freezing, yeasts and molds were more abundant on the acid fruits. From the microbiological standpoint the method of packing (water, brine, or dry pack) was not an important factor. Even after they had been frozen for 9 months, frozen products were found to contain sufficient numbers of microorganisms to cause rapid spoilage after defrosting. This increase was particularly marked with vegetables in which the spoilage organisms are bacteria, many of which cause proteolysis; with fruits spoilage is due to yeasts and, to a lesser extent, molds (78).

Pronounced differences were found in the ability of bacteria of different types occurring on frozen-pack vegetables to withstand freezing. Micrococci and species of Flavobacterium were the most resistant, 
micrococci in particular comprising a much greater proportion of the organisms in the frozen product as compared with the freshly packed material (79). The greater resistance of coccal forms (e.g. streptococci) to freezing than of coliform bacteria was further brought out in studies of suitable indicators of fecal pollution in frozen-pack vegetables. These studies showed that whereas the coliform test was more efficient than the enterococcus test for material before freezing, the fecal streptococci are the superior indicators in a frozen product (3). In a special study of the micrococci to note the presence of food-poisoning (enterotoxin-producing) forms, of 50 strains of staphylococci isolated from frozen vegetables, 12 were found capable of elaborating enterotoxic substances in appropriate media and four in elaborating them in frozen-pack corn held at room temperature (35).

The whole series of studies showed that frozen vegetables and fruits may be kept safely with reasonable care in handling to prevent development of spoilage organisms. This involves, apart from care in washing and blanching to minimize the microbial load, prompt and uninterrupted freezing and prompt consumption after defrosting. Moreover, the work indicated emphatically that products once defrosted should not be refrozen.

\section{Fruits and Vegetables (Dehydrated)}

Though the drying of foods is an age-old method of preservation, little was done towards developing this industry in Canada until the First World War. However, in spite of a number of improvements made under the exigencies of wartime conditions, lack of consumer interest during the postwar period resulted in a diminishing market for dehydrated products, due in large measure to great variability in quality and general preference for canned or frozen food. However, immediately before, and particularly during, the Second World War, when conservation of space and weight was essential, interest in dehydration was greatly stimulated. For several years, commencing in 1938, the Bacteriology Division studied the microbiological aspects of dehydration in cooperation with the Division of Horticulture and the Fruit and Vegetable Division, the concerted efforts of the Department being designed to assist the industry in turning out the best product possible.

The work soon showed enormous differences in the microbial content of products packed under commercial conditions; however, products dried experimentally could be produced with very low counts. The microbial load was found to be an important factor in affecting keeping quality, its magnitude depending upon the extent of the original contamination (which varied with the type of product), the effectiveness of washing and especially of blanching, and the degree of recon- 
tamination during drying. Furthermore, spoilage following rehydration was related to the microbial load of the finished product.

Cooperative plant studies involving extensive 'line tests' made it possible to determine the critical stages in the manufacture of dehydrated products affecting contamination, and consequently the life of the dried material (34). As a result, there was an enormous and sustained improvement in the quality of Canadian dehydrated products packed during the war. While in 1939-1940 only 40 percent of the output showed bacterial counts below 50,000 per gram, this figure had risen to 97 percent by 1945, and the incidence of samples positive for coliform bacteria (in $1 / 20$ gram) fell from 52 percent to 6 percent during the same period. This improvement could be attributed, not only to improved processing, but also to the effective supervision of the industry by the Fruit and Vegetable Division, as well as to the development of analytical procedures which permitted the introduction of microbiological standards.

\section{Fruits and Vegetables (Canned)}

Studies in which laboratory research was coordinated with plant practice were devoted for some years to problems of the canning industry, as to other means of preservation. Thus gaseous spoilage occurring in canned tomato products in Eastern Canada was found attributable to lactobacilli, chiefly Lactobacillus lycopersici and $L$. gayoni, and to yeasts of the Saccharomyces type, the latter being more prominent in spoilage of spiced products. Detailed investigation of the factors that contribute to spoilage showed the influence of the percentage of solids, of traces of metals, of the temperature of processing, as well as of recontamination possible at various stages (33). In British Columbia gaseous spoilage, accompanied by butyric odor, was found to be caused by Clostridium pasteurianum. In this case the maintenance of a suitably acid $\mathrm{pH}$ value, in conjunction with a suitable processing temperature, provided control (2).

The application of the Howard mold count procedure for control of Canadian tomato products, following a study by the Division which led to the introduction of standards suited to domestic conditions, has helped greatly in improving the quality of the material being processed. In the maintenance of quality, the Fruit and Vegetable Division played a prominent role. The studies illustrated the need for rigid inspection of the initial stock and for emphasis on trimming operations. The work led to the establishment of a short course in a 'mold count school', through the initiative of the Bacteriology Division in cooperation with 
the Ontario Agricultural College, to provide instruction for the control staffs of Canadian canneries in the technique and application of the mold count.

\section{Animal Products (Bacon Curing)}

Research on microbiological aspects of the curing and packing of Wiltshire bacon, an important item of export to the British market before and during the Second World War, was inaugurated by the Division in 1935 in collaboration with the packing industry. Defects observed by Department of Agriculture inspectors at the ports of entry in the United Kingdom were mainly off-flavor, discoloration, and slime, and the need for maintaining high quality in this product justified research aimed at determining the agents and conditions responsible for such defects as well as steps needed to ensure freedom from spoilage. Because of the special urgency brought about by the outbreak of war, investigations of the problem of bacon curing were also undertaken by the National Research Council, partly in collaboration with the Division, and the work of this organization led to findings of much significance.

One feature of the earlier work of the Division was concerned with devising suitable methods of bacteriological analysis based on physiological studies, related particularly to the salt tolerance of bacteria encountered in the curing pickle and on bacon sides at all stages of the process (56). The development of procedures proved to be an essential prerequisite to the detailed study of the numbers and types of bacteria contaminating the sides, their ability to survive or develop, their significance in the pickling process as well as in later stages of manufacture, and, finally, their responsibility for causing defects in the finished product.

Among the more significant results was the finding that many types of bacteria that contaminated sides before pickling were able to survive the pickling process. Since these types are chiefly nonhalophilic organisms, unable to grow in the heavy brine of the pickle, whose salt concentration approaches saturation, they are mostly inactive in pickle. However, 80 percent or more of precuring contaminants were found able to withstand the pickling stage and so were able to contribute to later storage defects. The surprising ability of such organisms to resist, if not multiply in, the high salt concentration of curing brine could be attributed to a protective action of substances in the pickle, since their resistance was much less in nutrient solutions of similar salt concentration. In the pickle itself, where reduction of nitrate to nitrite is an important function of the microflora in contributing to meat color, the active organisms were chiefly true halophiles, characteristic of the salt 
environmient, rather than precuring contaminants. The finding that the latter types could persist justified adoption of measures for the utmost plant sanitation in Wiltshire bacon processing (12).

\section{Animal Products (Poultry)}

During the period 1934-1935 studies were undertaken at the request of the Poultry Division and the Livestock Branch, and in cooperation with the National Research Council, on bacteriological aspects of the deterioration of dressed poultry held in storage at chill temperatures around $0^{\circ} \mathrm{C}\left(32^{\circ} \mathrm{F}\right)$. Though it was known that certain cold-tolerant bacteria are able to develop at temperatures as low as $-7^{\circ} \mathrm{C}\left(18^{\circ} \mathrm{F}\right)$, information was needed about microbial action on this product and factors affecting keeping quality.

The findings showed that deterioration to the point where the poultry acquires a noticeable odor and consequently loses its marketability is essentially a surface spoilage. This is because the bacteria develop on the skin surface to such an extent that they become objectionable before there is any decomposition of, or significant increase of bacteria in, the muscular tissue. It was established that the first sign of surface odor became apparent when the bacteria count on the skin exceeded approximately 2.5 million per square centimeter. At temperatures approximating freezing, a decrease of 2 degrees delayed the initial stage of spoilage for one week. The predominant types of bacteria involved were found to be species of Micrococcus, Flavobacterium, and Achromobacter (80).

Chlorine disinfectants and brine, used as dips, were ineffective in suppressing growth of surface bacteria at chill temperatures. Mineral oil, applied as a spray, reduced bacterial numbers, while dipping in wax increased the period during which poultry remained in good condition.

\section{Animal Products (Eggs)}

Although small quantities of spray-dried egg powder had been produced in Canada before 1940, the decision of the British Ministry of Food in that year that all eggs should be received in powder form created serious problems in ensuring high quality in the greatly expanded Canadian output. In cooperation with the Special Products Board, the National Research Council, and the drying plant operators, this Division devoted attention to bacteriological aspects of this wartime product.

Following preliminary studies to aid in establishing bacteriological standards for egg powder, the Division, in 1943, assumed responsibility for the official bacteriological control of powder shipped to Britain. At 
the same time, attention was given to devising suitable methods of providing information not given by the plate or 'viable' count made on the finished product, on the sanitary conditions prevailing at the plants and on the care given the egg melange up to the point of drying. As a result, a direct microscopic method was evolved which proved of such value that it was incorporated with the specifications (26). Furthermore, for plant sanitation studies, a modification of the 'Burri slant method' for milk was worked out, and it proved most effective in locating sources of bacterial contamination and so in helping to maintain quality (22).

Cooperative studies of the same kind were made in aid of the frozen egg industry, which developed both domestic and export markets, particularly during the years following the war. As with egg powder, the work included investigations of the most appropriate procedures for the bacteriological evaluation of quality, cooperation in setting up standards, and the application of procedures suited to the maintenance of plant conditions for ensuring high quality and the screening of unsuitable raw material $(27,28)$.

\section{SOIL MICROBIOLOGY}

As pointed out earlier, the more basic aspects of research in soil microbiology were given continuous study in the work program of the Division from its establishment in 1923. At the same time some of the more practical aspects of the work were emphasized (to a proportionately greater degree during the earlier years) through developmental work, supported by laboratory, greenhouse, and field studies relating particularly to the inoculation of soil and seed. This latter aspect of soil microbiology is mentioned first.

\section{Soil and Seed Inoculation (Rhizobium)}

Forty years ago the value of inoculating the seed of leguminous crops, now recognized as a distinct aid to good farming practice, particularly where a specific legume is being grown for the first time or where previous plantings have been unsuccessful, was not as widely appreciated as now. To better acquaint farmers with the value of seed inoculation, the Division furnished free to any farmer who wished to make a trial sufficient culture of the proper species of Rhizobium for the treatment of 60 pounds of legume seed. An effort was made to induce the recipients of cultures to include an uninoculated control, to report the results of their tests, and to supply relevant information about soil and previous cropping history to aid in assessing the efficacy of inoculation under field conditions. 
This distribution was maintained for 13 years, during which time 54.529 cultures were prepared and sent out. It was felt that this effort aided materially in making farmers better aware of the advantages of seed inoculation. Of 2475 reports 79.9 percent showed benefit resulting from treatment; in the case of alfalfa, the most commonly treated crop, 85.1 percent of the reports indicated a favorable effect of inoculation where this legume was grown for the first time. With increased awareness of the value of inoculation by our farmers and growers and the consequent availability of commercially prepared inoculants, general distribution by the Division was discontinued in 1937 .

That inoculation is especially important in newly developed areas was strikingly demonstrated at the Dominion Experimental Station in the Peace River district at Beaverlodge, Alberta, as a result of cooperative experiments extending over several years and described in the reports of the Superintendent, W. D. Albright (1). Seedings of alfalfa, sweet clover, red clover, and alsike had never been very successful until inoculation was started. The increased resistance of inoculated crops to winter-killing was shown to be very marked.

The viability of the symbiotic nitrogen-fixing organism, Rhizobi$u m$, on inoculated seed is a matter having important implications. Although this organism is known to exhibit considerable resistance to such adverse conditions as cold and desiccation, it has always been considered that for best results seed should be inoculated immediately before planting. However, in ordinary practice it is often necessary to delay seeding after treatment because of adverse weather or other circumstances. Following a two-year series of laboratory and greenhouse tests to study the longevity and nodule-producing capacity of the organism, the work was extended in a series of field experiments at the Experimental Station at Beaverlodge that lasted several years.

Inoculated alfalfa seed was found to retain, after storage for six months, bacteria capable of producing nodules, the viability of the organisms being maintained best at cool, though not freezing, temperatures. However, numbers of bacteria, as well as their nodule-forming capacity, declined on storage, more rapidly during the first weeks, and more gradually thereafter (61). Though the results pointed to the value of immediate seeding of inoculated seed, field tests were needed to translate into terms of crop yield the effect of delayed seeding. The findings, based on seedings made in three successive years, with measurements of crop yields in three successive seasons for each seeding, showed that, contrary to prevailing opinion, holding inoculated seed for as long as one to two weeks does not necessarily lessen the effectiveness of the treatment. It was shown that inoculation may show 
a delayed action and the beneficial effect may become most evident in the second or succeeding years as the organism becomes better established in certain soils $(1,94)$.

\section{Soil and Seed Inoculation (Miscellaneous Cultures)}

The practical value of soil or seed inoculants other than those for leguminous crops has long been viewed with skepticism, owing to the lack of acceptable evidence of their efficacy. However, coincident with the rise of interest in legume inoculation, there appeared on the market various highly priced commercial 'cultures' purporting to be of value for the treatment of all kinds of crops, and accompanied by pseudoscientific claims of effectiveness. To protect Canadian farmers and growers by assessing the worth of such preparations, the Division, at the request of the Production Service, made extensive laboratory and greenhouse studies, as well as cooperative field trials at Ottawa and other Experimental Stations, on products passing under such names as 'Soilgro', 'Soil-vita', 'Vitamite', 'Growmore', and 'Jermite'. The exhaustive tests failed to show any practical worth of such products for the growth of nonlegumes; the results emphasized the view that inoculation was of value only in the case of leguminous crops (64).

With a change in Departmental regulations covering the marketing of bacterial cultures to require that claims for preparations purporting to aid plant growth should be accompanied by evidence acceptable to the Minister, the control of such cultures was rendered easier, and indeed they soon disappeared from the Canadian market.

Based on the ability of the nonsymbiotic bacterium, Azotobacter, to fix atmospheric nitrogen, many attempts have been made to apply cultures of this organism to seed or soil with the object of increasing crop growth. Though no unequivocal success had been demonstrated in the earlier experiments, postwar studies in Europe, particularly in the USSR, had led to claims of increased yields with a variety of crops. These reports suggested the desirability of reexamining the value of Azotobacter as a crop inoculant under Canadian conditions.

In cooperation with the Dominion Experimental Farms, field experiments were carried out with three crops at stations varying widely in geographic location: tobacco at Ottawa and Delhi, Ontario; oats at McLennan, Alberta; and oats and potatoes at Whitehorse, Yukon. The cultures used for 'bacterization' were prepared from strains of Azotobacter isolated from the rhizosphere of plants of the kind treated. No significant effect of inoculation on the yield of any of the crops studied could be noted. A special study of the colonization of Azotobacter on the root system of tobacco showed that the organism could migrate to a depth of 10 inches in the soil; in spite of this it 
failed to stimulate growth of the plants or to furnish additional nitrogen (107). The findings support the view that in those instances where Azotobacter has apparently been of benefit, this is to be ascribed to some stimulation during the early stages of development because of growth substances produced by the organisms rather than to an increase in the available nitrogen supply.

\section{Approach to Basic Research in Soil Microbiology}

If the whole period under review is considered, soil microbiology engaged the largest share of attention devoted to the more fundamental aspects of research in the Division. In soil microbiology attention had been directed, for the most part, towards the study of processes in which microorganisms are known to participate rather than towards an objective study of the microorganisms themselves, and, although valuable data have been gathered on biological processes known to occur in soil, such as ammonification, nitrification, nitrogen fixation and others, the organisms concerned have been studied largely because of their known functions. However, little attention has been paid to groups of organisms whose functions are unknown but which comprise a large proportion of the micropopulation of arable soils.

An attempt has therefore been made to strike a better balance by developing the 'biological' as contrasted with the 'functional' approach to the study of soil microorganisms. Whereas this latter type of investigation concerns itself with known functions, the former starts out by learning, first, something about the indigenous microorganisms of soil and, ultimately, their functions (85).

Based on these considerations, the program of work was largely concerned with studies which, falling within the general category of 'qualitative' investigations, relate to such topics as microbial ecology, the nutrition of microorganisms, the microbial equilibrium in soil, associations and antagonisms, as well as the plant-microbe relationship and extensions of this latter to certain soil microbiological aspects of soil-borne plant disease. Since no real line of demarcation exists between such topics, the various projects undertaken embraced studies which, for the most part, included aspects of several of these interrelated themes. For convenience they may be discussed under the following headings selected to indicate where the main emphasis lay.

\section{Ecology}

The first project in soil microbiology undertaken in the Division was a study of microorganisms in frozen soil. Widely divergent views had been held on the effect of winter freezing, the most generally held being that numbers of soil bacteria increase with the development of a 
'winter flora,' especially adapted to growth at low temperature. Another view maintained that microorganisms were seriously depleted, while it was held by others that, although increased numbers are found, these are to be ascribed to the breaking up of clumps through frost action without any real cell multiplication. Since the matter was of significance in Canada where the soil over large areas remains frozen for several months, clarification of the problem was sought through studies during two winters.

Observations on the persistence of bacteria, actinomycetes, fungi, and protozoa gave no support to the hypothesis of a 'winter flora' (or fauna) in frozen soil. Although numbers were well maintained throughout the period of frost, there was no evidence of a stimulation by freezing, nor was there any sign of a breaking up of bacterial clumps, or a rise of organisms from lower, unfrozen depths. Microorganisms of frozen soil are to be regarded as cold-enduring rather than psychrophilic. Under conditions of frost, microbiological activities are largely suspended, but in spite of this seasonal cessation of activity numbers are not depleted, so that with the advent of spring there is no lack of soil microorganisms (58). From a qualitative study it was shown that the bacteria of frozen soil were similar to types occurring in soil at other seasons (59).

Bacteria of the genus Arthrobacter comprise a group of soil organisms with unusual pleomorphic characters and they are now evoking much attention. The occurrence of the type species, Al globiformis (Bacterium globiforme), was first believed to be related to the productivity of the soil, because it had been reported to occur abundantly in fertile soils and sparsely in unproductive soils. The value of having a method based on the incidence of a single organism for comparing the crop-producing power of soils was such that a study was made of its occurrence in a wide variety of soils from many regions of Canada.

No relationship between numbers of $A$. globiformis and soil fertility could be established. Although the organism underwent a severe selective repression in acid soils of $\mathrm{pH}$ below 5.0, it occurred abundantly in soils above pH 5.0. Organisms of the A. globiformis type, which represented roughly 10 percent of the bacteria obtained by plating methods, were seen to represent a very important group of the indigenous soil microflora $(99,100)$.

Related to the question of nitrogen fixation was a quantitative study of the persistence in soil of Azotobacter, as well as of three species of Rhizobium ( $R$. trifolii, $R$. meliloti, and $R$. leguminosarum). Numbers were determined at four-week intervals throughout a fouryear crop rotation period in three soils that had received no fertilizer, farmyard manure, and artificial fertilizer respectively for twenty years, 
and consequently they varied greatly in crop-producing capacity. $R$. trifolii, the only species with a host plant in the rotation, occurred in much greater numbers than the other species of Rhizobium, not only immediately following clover, but in succeeding years and, although with this species little difference was noted in the three soils, the other two species persisted in much higher numbers in the fertilized areas than in the unfertilized soil. On the other hand, numbers of Azotobacter were consistently higher in the unfertilized soil, with much greater seasonal effect noticeable than in the case of the rhizobia. However, the generally low incidenee of Azotobacter supported the view that the part played by this organism in fixing nitrogen in field soil was to be regarded as of doubtful significance (86).

A request from the Pacific Science Board of the United States afforded an opportunity to examine the bacterial and actinomycete floras of a series of soils from Arno Atoll in the Marshall Islands of the South Pacific as part of an ccological study of this region under the auspices of the Board. Among the findings of interest was the relative scarcity of nitrifying bacteria which occurred only in the surface layers. Of the Azotobacter types found, A. vinelandii was the most prevalent. Despite a generally low incidence of streptomycetes, a high percentagc of this group possessed antibacterial activity (95).

\section{The Indigenous Soil Bacteria (Basic Principles Pertaining to Methods)}

The primary isolation of the indigenous bacteria of soil requires the use of as nonselective a medium as possible. This is in contrast with the almost universal use of more or less highly selective media which favor definite physiological groups. As the least selective medium, soil extract agar, without addenda, was used for plating so that representative forms might develop with least suppression by types preferentially favored by incorporation of special energy sources.

The value of any qualitative study is enhanced when quantitative aspects are also taken into account; indeed, these aspects are essential in investigations of the microbial equilibrium. Haphazard selection or assumption of identity on the basis of colonial or microscopic appearance is unsuited to an estimation of the relative incidence of different types. Consequently the procedure adopted was to isolate all colonics on a series of representative plates until 100 to 200 were picked for detailed study. Therefore the use of a nonselective medium and the isolation of cultures on a systematic basis were the two cardinal principles applied to the qualitative study of soil bacteria. 


\section{The Indigenous Soil Bacteria (Morphology and Physiology)}

When classified according to morphological types, the indigenous soil bacteria could be divided into eight main groups. Nonspore-forming short rods, of which five groups were recognized, comprised 80 to 90 percent of all types. The most prevalent single group consisted of Gram-negative short rods, which were somewhat more numerous than Gram-positive short rods. The other short forms included Gram-variable short rods, coccoid rods, and pleomorphic rods. The findings helped to establish as an intergral component of the soil microflora this last-named group, known as 'soil diphtheroids,' forming approximately 10 percent of the bacterial population, and characterized by a high degree of pleomorphism. Their obvious relationship to Corynebacterium suggested attachment to this genus, though later work favored their being regarded as a generic entity, Arthrobacter, characteristic of soil. The remaining groups were cocci, nonspore-forming long rods and sporeformers, all less prominent with respect to numbers.

The predominant bacteria were comparatively inactive in single culture, considerable divergence in biochemical action being shown by forms closely related morphologically. The study suggested that the organisms are unstable physiologically, that they possess considerable adaptability, and that their functions are exercised more fully under conditions of association. It was also brought out that in soil of a particular type there exists a surprisingly uniform balance between the various morphological and physiological groups of the autochthonous (indigenous) microflora, even though productivity may vary greatly (101).

\section{The Indigenous Soil Bacteria (Nutrition)}

A knowledge of the morphological and physiological characters of soil bacteria is admittedly required for an understanding of the kinds of bacteria inhabiting soil. However, it has become increasingly apparent that criteria other than those based on morphology or the 'classical' biochemical tests commonly applied for differentiation were needed for any insight into the significance of the soil microflora and its relationship to plant growth or plant health.

It is self-evident that the equilibrium between various groups of organisms existing in soil at any time depends largely upon the availability of nutrients required for their growth. Though certain antagonisms may distort this relationship, in the main the relative incidence of a group of microorganisms requiring a definite kind of nutrient will depend upon the availability of that nutrient in soil. A method was therefore developed for classifying soil bacteria according to their nutritional requirements (71). The procedure was to test isolates, 
obtained by nonselective methods referred to, in seven differential media, ranging from a simple basal medium to those of increasing complexity, containing amino acids; growth factors; anino acids plus growth factors; yeast extract; soil extract; and yeast extract plus soil extract. Measurement of growth response provided a means of classifying the organisms and estimating the incidence of the seven groups in any soil. This procedure, representing a new approach to the grouping of soil bacteria, has been helpful in studying the microbial equilibrium in soil, not only for season and soil treatment but also for plant growth, and it has been applied advantageously to studies on the relationship existing between soil microorganisms and certain soil-borne plant diseases. It has also been the basis for research into the nature of the growth-promoting properties of soil.

\section{The Indigenous Soil Bacteria (Growth Factors)}

The differentiation of the soil bacteria according to their nutritional requirements brought to light a substantial group of soil bacteria that depended for growth upon some essential factor or factors contained in extracts of soil and not furnished by combinations of normally adequate bacterial nutrients, including amino acids, yeast extract, or growth factors known at the time. Attention was therefore focussed on this special group of organisms, as well as on the general vitamin requirements and the vitamin-synthesizing ability of the indigenous microflora.

It was found that for most, though not all, of the bacteria depending upon soil extract, the growth-promoting effect of the latter could be replaced by vitamin $B_{12}$, which had been recently discovered. The requirement for vitamin $B_{12}$ had been generally believed to be restricted to a small group of bacteria, chiefly lactobacilli. However, it was apparent that this requirement is displayed by an important ecological group of bacteria comprising part of the indigenous soil microflora (88). Subsequent axonomic study of $\mathrm{B}_{12}$-requiring forms revealed ten types, which belong to four generic groups. The most prominent group was Arthrobacter (70).

Other more exacting bacteria, for which vitamin $\mathrm{B}_{12}$ was unable to replace soil extract, remained dependent upon unkown growth-promoting substances. A study of such fastidious organisms showed that a factor required for their growth could be synthesized by certain other soil bacteria having very simple nutritional requirements, such as the species to which the name Arthrobacter pascens was given. Further investigations of the nature of the growth factor showed it to be a previously unrecognized substance (69). It was referred to as the 'terregens factor' (TF), since it was first found essential for the species 
named Arthrobacter terregens. Highly potent concentrates could be prepared from culture fluids of $A$. pascens that showed activity at one part per 1000 million (6). It was estimated that TF-requiring bacteria were roughly one-tenth as numerous in soil as those requiring vitamin $\mathrm{B}_{12}$.

\section{Microbe-Plant Relationships (Seed)}

In a consideration of the relationship that exists between plants and soil microorganisms a distinction may be made between mutual effects in the seed, the growing plant and the decomposition of plant residue incorporated in soil. All three aspects of these associations have been given study; however, main attention has been devoted to the growing plant ('rhizosphere effect') for in this case the mutual effects reach their highest level of significance.

A study of 2130 cultures of bacteria, isolated nonselectively from seeds of wheat, oats, red clover, alfalfa, timothy, and flax and compared on the basis of morphology, physiological activity, and nutritional requirements, showed that seeds harbor a characteristic microflora different from that predominant in soil. There was evidence of a certain specificity in the microflora associated with the various crops. Gramnegative, nonsporing, nonpleomorphic rods comprised most of the seed organisms. Seed-borne bacteria exhibited a higher degree of physiological activity than those predominant in soil, and they required much less complex nutrients. Similarity was found to exist between seed bacteria and those of the rhizosphere. It could be postulated from the evidence that the rhizosphere organisms constitute a group morphologically, physiologically, and nutritionally intermediate between the indigenous soil bacteria and the epiphytic seed microflora (110).

\section{Microbe-Plant Relationships (Rhizosphere)}

Though it had been known for many years that in the rhizosphere microorganisms are more abundant than in soil that is free from the influence of the roots of growing plants, lack of information of a qualitative nature on the effect of plant growth on the soil microflora prompted a series of investigations to examine the more specific aspects of the 'rhizosphere effect.'

In proximity to the plant, the bacterial equilibrium of the soil was found to undergo definite alterations, so that apart from increases in total numbers there was evidence of a selective action characteristic of all plants studied. Gram-negative short rods were found to be preferentially increased, while Gram-positive short rods, coccoid rods, and spore-forming bacteria were suppressed. In bacterial physiology, one of the outstanding effects of plant growth was the stimulation of the 
activity (quite apart from numbers) of the microorganisms. The rhizosphere, compared with soil beyond the zone of influence of the plant, showed higher proportions of chromogenic and motile form, of proteolytic organisms and of carbohydrate fermenting types. Such findings, considered in conjunction with the pronounced numerical increases in the rhizosphere, pointed to a phenomenal stimulation of microbial activity with the shift of equilibrium adjacent to the plant root (67).

Application of the method of 'nutritional grouping' showed that, in soil adjacent to the plant, profound and characteristic changes occur in the equilibrium in the bacterial nutritional requirements. The outstanding features of these changes are the preferential stimulation of organisms requiring amino acids and the relative suppression of those dependent upon the complex nutrients provided in soil extract (84, 87,109 ). Bacteria with simplest requirements (able to grow with inorganic nitrogen) were increased, while the opposite effect was noted with those requiring growth factors. The whole change was a shift towards less complex requirements. Though the various crops studied conformed to a general pattern, the studies brought to light certain specific crop effects on the incidence of bacteria with different nutritional requirements (109). In the main, the differences were between legumes and nonlegumes, though within both groups indications of specific effects were observed. More light on such effects is needed, because one possible value lies in providing a better understanding of certain fundamentals of crop sequence.

The increased relative incidence of bacteria requiring amino acids, noted with all crops studied and constituting the outstanding rhizosphere effect, provided strong circumstantial evidence that liberation of amino acids from roots was the chief factor to account for the increased availability of these compounds in soil in the immediate vicinity of the root system. Direct evidence was obtained in studies which showed that amino acids could be liberated from a variety of plants to a degree that was noticeably increased by drying and remoistening of the soil, and that amino acids so detected could be utilized by amino-acid-requiring bacteria (52).

Knowledge of the influence of the plant on various groups of microorganisms as well as on different physiological groups of bacteria was revealed by a comprehensive field study of the rhizosphere effect of mangels (38). The effect was much more pronounced with bacteria than with actinomycetes or fungi. Of special interest was the demonstration of an effect with protozoa and with algae in the latter part of the growing season. In general, more slowly growing plants manifested this selective power when approaching maturity. Of the bacterial groups, ammonifying and denitrifying organisms reacted strongly to 
plant growth, and cellulose decomposing and gas-producing clostridia to a lesser degree, while with Azotobacter no rhizosphere effect was apparent. With all types the extent of the effect was affected by fertilizer treatment through its influence on the rate of plant growth, while the sterilization of soil, by altering its physical and chemical properties, influenced in marked fashion the degree of the rhizosphere effect $(50)$. That the rhizosphere effect is initiated early in the life of the plant was shown in tests with seedlings; even after three days it could be demonstrated plainly with bacteria, and to a lesser degree with fungi (102).

\section{Microbe-Plant Relationships (Crop Residues)}

A further aspect of the relationship between soil microorganisms and crops concerns the effect of the decomposition of plant material in soil. Findings derived from studies on the incorporation of six cover crops in soil on the incidence of the nutritional groups of bacteria showed that the addition of plant tissue exerted a much less pronounced effect on the balance between the nutritional groups than the same plants when growing. The data pointed to shifts similar in kind to, though less in degree than, the rhizosphere effect in showing a trend owards higher proportions of organisms with simpler requirements and lower relative incidence of organisms needing complex nutrients. With progressive decomposition the effect becomes less marked as conditions slowly approach the more stabilized state of normal soil (93).

The only indication of a specific, as distinct from a general, crop effect concerned the relationship of vitamin $\mathrm{B}_{12}$ to alfalfa. In soil following decomposition as well as in the rhizosphere, numbers of $\mathrm{B}_{12}$-requiring bacteria were in all cases highest with alfalfa. These findings, considered in conjunction with studies that showed the alfalfa nodule organism, Rhizobium meliloti, to be capable of synthesizing significantly higher amounts of this vitamin than other species (6), strengthened the belief of a special association existing between vitamin $\mathrm{B}_{12}$ and alfalfa.

\section{Soil Microorganisms and Plant Disease}

Although there has been increasing awareness that the microbiology of the rhizosphere concerns not only the growth but also the health of plants, and that the full implication of what is called the 'rhizosphere effect' embraces interactions of not only the plant and soil microflora, but also the soil-borne pathogen, the liaison between soil microbiologist and plant pathologist has been for a long time all too meagre. However, the Bacteriology Division has studied certain aspects of soil microbiology related to plant pathology, with extensions of the work in the form 
of cooperative investigations with the Botany and Plant Pathology Division at St. Catharines and Saskatoon.

The possibility that resistance to certain soil-borne diseases might be related to differences in the influence exerted by certain varieties of plants upon the soil microflora prompted a series of investigations. The work brought to light differences in the rhizophere effect exerted by varieties of flax resistant and susceptible, respectively, to wilt induced by Fusarium oxysporum f. lini, and by tobacco varieties varying in resistance to black root rot caused by Thielaviopsis basicola. Based on comparative studies with plants free from infection, the work showed that the susceptible varieties exerted a more pronounced rhizosphere effect than did the corresponding resistant varieties. The numbers of microorganisms were greater in the rhizosphere of susceptible plants than in that of resistant plants, and there were greater rhizosphere-soil ratios'. In addition, consistent differences of a qualitative nature were noted in the proportions of various morphological and phys:ological groups of organisms $(67,103,112)$.

The findings suggested that resistance or susceptibility might be correlated with inherent differences in the nature of excretions liberated from the plant roots, a hypothesis that found support in further work. Whereas the susceptible variety of flax favored such genera as Fusarium and Helminthosporium in the rhizosphere, the resistant variety induced a preferential stimulation of Trichoderma, some species of which are antagonistic to various pathogenic fungi. Growth of these same types was affected in an analogous manner by hydrocyanic acid, which was found to be liberated in much larger quantities by the resistant variety (104).

The possibility was investigated that the balance between certain nutritional groups of bacteria might be related to the severity of pathological manifestations in certain crop diseases that cause root injury. This was borne out in studies of strawberry root rot at St. Catharines, which showed that certain bacterial groups were favored, and others suppressed, under conditions which augmented the severity of root rot. It was therefore attempted to express the bacterial equilibrium of the condition of the soil on a numerical basis by assigning positive and negative values to the percentage incidences of the groups associated respectively with lesser and greater severity of the disease. The sum of these values was designated the 'bacterial balance index' (13, 113). This index was found to vary with soil type and season, and was normally higher in the rhizosphere than in soil distant from the plant. Its application to soils variously modified by treatment to alter their content of the disease factor showed a striking inverse correlation of the index with the disease potential $(13,51,111)$. Analogous findings 
were later obtained in a study of the bacterial equilibrium of potato scab. There was a rise in the bacterial balance index as the severity of the disease diminished after various soil treatments, differences in equilibrium being shown in most accentuated fashion in the rhizosphere (92).

In an approach towards the control of common root rot of wheat, cooperative work initiated at Saskatoon was directed towards the reduction or elimination of spores of Helminthosporium sativum in soil to reduce the degree of infection following germination induced by the presence of the susceptible host. The findings suggested a new mechanism to aid in control that was based on the observation that germination of the conidia of the pathogen, normally dormant in natural soil, could be stimulated by the addition of certain organic materials such as soybean meal. Germination so induced was seen to be followed by lysis of the germ tubes, a result which thus rendered the spores incapable of infecting the crop if effected prior to seeding (11). The work was greatly facilitated by the development of a technique for observing the germination and subsequent disintegration of the germ tubes (10).

Studies on the nutrition of $H$. sativum, carried out as a corollary of this work, revealed the importance of trace elements, especially zinc, in the growth of this fungus; however, vitamins were unimportant, though certain amino acids, particularly $l$-proline, were stimulatory (90).

In a study of gray speck disease of oats, considered to be related to a deficiency of manganese, field and greenhouse studies, conducted in cooperation with the Cereal Division, showed that varieties susceptible to this nutritional disorder could show characteristic symptoms in spite of an adequate supply of the element in the soil. Since soil was known to harbor manganese-oxidizing microorganisms, an explanation was sought through comparative studies of the rhizosphere of oat varieties varying in resistance to gray speck. The susceptible variety was found to stimulate the development of organisms capable of oxidizing manganese to a form unavailable to the plant, and thus a hypothesis was provided to explain symptoms of manganese deficiency. Further confirmation accrued from studies on the partial sterilization of 'sick' soils. Amelioration of the disease by application of certain fumigants could be correlated with a reduction of microorganisms capable of oxidizing manganese. Certain treatments of soil, for example the application of straw mulch, which increased the severity of the symptoms and reduced the crop yield, stimulated development of manganese-oxidizing forms (105). 
The presence of microorganisms in the soil that are antagonistic to certain other forms, including plant pathogens, and interest in the possible use of such organisms in helping to control soil-borne disease suggested a series of studies on their distribution and their capacity for exerting suppressive action in soil.

In view of the known capacity of many actinomycetes for producing antibiotics, attention was directed mainly to this group. Opportunity to examine soils from Northern Canada was made possible by the cooperation of the Entomology Division in securing samples from five regions, including Cornwallis Island. A high incidence of antagonistic forms was found, 61 percent of 660 isolates showing antagonism against at least one of eight test organisms, including three plant pathogenic fungi. The incidence of antagonistic actinomycetes varied, not only with location, but also with depth, being consistently higher at 6 inches than at higher or lower levels (57). In a special study of 46 strains showing a high degree of inhibition of Streptomyces scabies and Helminthosporium sativum a wide range of cross-antagonisms was found to exist within the group (89).

It had previously been found in studies directed towards the problem of potato scab that a complex pattern of cross-antagonisms existed within a group of 11 actinomycetes showing antagonism towards S. scabies out of 90 strains isolated from the rhizosphere of potato in scab-infested soil that had been favorably modified by incorporation of soybeans. The findings indicated the value of employing, for possible use in disease control, strains of antagonists which are themselves not susceptible to the action of other strains (82).

Though the antagonistic action displayed by certain microorganisms in soil had been ascribed chicfly to the production of antibiotics, direct evidence had been meagre owing to the difficulty of detecting such substances in natural soil itself. Preliminary work dealt with a study of the elaboration of antibiotics by species of Penicillium and Streptomyces under controlled conditions provided by a modification of the Lees and Quastel soil perfusion apparatus. Though sterile or partially sterilized soil was used, the work showed certain factors that affect the formation of antibiotics in soil and provided a basis for further study (97).

Subsequent work was carried out with actinomycetes, selected for their antibiotic activity towards $H$. sativum, and shown to reduce root rot of wheat when inoculated with the pathogen. In vitro examination of the effect of antibiotics produced by the antagonists showed inhibition of germination, and, if tested following germination, characteristic morphological changes in the hyphae. It was found that in natural soil 
the effects of the actinomycete were similar to those of the antibiotic in vitro; failure to detect free antibiotic by extraction strongly suggested that the latter is concentrated in the vicinity of the antagonist, producing a localized effect (96).

\section{GENERAL MICROBIOLOGY}

\section{Apiculture (Bee Diseases)}

Microorganisms affect the beekeeper in two ways, by causing disease to larvae as well as adult bees, and through spoilage of honey by fermentation. The Division engaged in extensive cooperation with the Apiculture Division in both directions.

The larval disease known as American foulbrood had long been a serious scourge of apiaries in Canada. Caused by Bacillus larvae, spores of which are extremely resistant to killing, it is most difficult to eradicate. Early work was directed towards a better understanding of the characteristics of this organism and the development of media and methods for its recognition in suspected combs (62). Further detailed study of its nutritional requirements and general physiology (46, 49, 68 ) led to practical field tests for the diagnosis of American foulbrood, which provided a basis for subsequent experiments on methods of prevention and eradication (47).

Considerable progress was made in the application of chemotherapeutic agents to control American foulbrood. Of the sulpha drugs, sulphathiazole and sulphadiazine showed greatest effectiveness as preventive agents, though it was important to point out that the application of such drugs required careful supervision and that indiscriminate use, with undue reliance on their effectiveness, could result in masking the disease and therefore aid in its dissemination $(39,40)$. The effect of antibiotics was also examined under laboratory and field conditions. Terramycin, fed in honey or syrup, provided the most effective protection; however, the sulpha drugs retained their potency on storage much longer than the antibiotics tested (44).

European foulbrood, an infectious disease of young larvae, has also been a serious problem, particularly in Western Canada. Considered to be a bacterial disease, though showing symptoms distinguishing it from American foulbrood, the etiology has been a matter of dispute. The precise roles played by several species of bacteria characteristically associated with the disease had not been satisfactorily resolved. The earlier studies dealt with the morphology and physiology of these organisms, particularly Bacillus alvei and Streptococcus apis, prominent in most cases of disease, and with their possible relationship to, or distinction from, Streptococcus pluton $(48,63)$. Though sulpha 
drugs provided no control over European foulbrood, encouraging results were obtained by use of antibiotics. In cooperative field tests with the Saskatchewan Department of Agriculture, terramycin and streptomycin, and to a lesser extent aureomycin, fed to colonies or sprayed on clean comb, effectively prevented the disease introduced naturally or artificially. The same antibiotics also reduced infection markedly when fed to diseased colonies (41).

In tests to control nosema disease of adult bees caused by a protozoan, Nosema apis, the antibiotic fumagillin was the most promising of a varicty of sulpha drugs, antibiotics, and antiprotozoan agents tested (43).

\section{Apiculture (Honey)}

Because of the serious loss to beekeepers and handlers through spoilage of honey by fermentation, the Division devoted considerable attention to the problem in a study of the agents responsible and the factors concerned. Fermentation was found to be caused by osmophilic (sugar-tolcrant) yeasts, and four new species that were able to thrive in the high percentage of sugar in honey (approximately 80 percent), which suppresses most microorganisms, were discovered (76). These yeasts could be carried with the nectar, while apiary soil could be progressively infected to serve as a continuing source of contamination (74). Though all honeys were found to contain sugar-tolerant yeasts, in amounts which varied with the geographical location, the tendency of honey to ferment was found to depend on the degree of infection and the moisture content (83). It was possible to devise a method of analysis that indicated with a high degree of probability whether a given lot of honey would ferment within a year under ordinary storage (65). Fermentation could be prevented by cold storage or pasteurization. It was subsequently shown that treatment with high-velocity electrons was effective in destroying yeasts in heavily infected honey at a dose of 1 to $2 \times 10^{6} \mathrm{r}(45)$.

Detailed studies of the osmophilic yeasts showed that they required small amounts of growth-promoting substances in honey (75). These factors were later identified as biotin, essential for all types, and pantothenic acid, inositol and thiamine, requirements for which varied with the species (81).

\section{Halophilic Bacteria}

These bacteria, which require salt, often in amounts as high as 20 percent, with some species developing at concentrations approaching saturation, comprise a specialized group of organisms of economic importance. Not only are they active in curing pickle and in other 
food-processing operations (12), but some species occur in spoilage of highly salted products. The early work concerned a study of the red discoloration of salted hides brought to the attention of the Division by the National Research Council. The defect, known in the trade as 'red heat,' had occasioned loss to the leather industry through spotting and weakening of the fiber.

From a series of salted hides from Canada and Argentina showing the defect, four species of red organisms and several nonchromogenic halophilic forms were isolated. Of the former group, two species with pronounced proteolytic properties were considered to be the types involved in serious damage to salted hides. One, identified as Serratia salinaria, had been previously shown to be a cause of red discoloration of salted codfish; the other was found to be a new species and named Serratia cutirubra (66). Subsequent studies added to our knowledge of the physiology and nutritional requirements of halophilic bacteria, having salt tolerances varying from low to high ranges, and including organisms from salted hides and bacon pickle (49), and Pseudomonas nigrifaciens, which causes discoloration in print butter (55). Studies on the metabolism of these organisms showed that an aspartate-glutamate transaminase was operative in $S$. salinaria, which required between 4 and 8 percent of sodium chloride and a $\mathrm{pH}$ of 8.0 for optimal activity (91). This enzyme system was also found in S. cutirubra and Vibrio costicolus though not in two species of halophilic Sarcina.

\section{Bacteriophage and Bacterial Plant Pathogens in Seed}

The successful application of bacteriophages to the detection and identification of bacterial species in medical bacteriology suggested studies in cooperation with the Botany and Plant Pathology Division to examine the possibility of using analogous methods for the detection of internally borne bacterial pathogens in seed. The isolation of specific phages for Pseudomonas phaseolicola and Xanthomonas phaseoli made possible the development of a procedure for the rapid detection of internally borne infections of beans with these organisms, which cause halo blight and common blight respectively. A rapid method that was devised, based on a phage count technique, revealed the presence of the homologous organism in preincubated material prepared from the seed (53). Later refinements of the method showed that the phage plaque count procedure was not only much more rapid, but also more reliable than the usual methods for detecting the pathogen. In cooperation with the National Research Council, the phage for $X$. phaseoli was revealed and measured (54).

Further work led to the isolation of a phage for Pseudomonas pisi, cause of bacterial blight of peas, and its application in detecting the 
presence of the pathogen in pea seed and in plant tissue from infected fields (98). Phages for various members of the Xanthomonas translucens group of bacteria from seed of cereals were also isolated, most with a high degree of specificity.

\section{2,3-Butanediol}

In cooperation with the National Research Council studies were undertaken on certain bacteriological aspects of the production of 2,3-butanediol by Bacillus polymyxa. Apart from its use as an antifreeze this compound may be converted to butadiene, a precursor of synthetic rubber. Chief attention was given to factors affecting the yield of glycol, such as the type of raw material, strain efficiency, nutrition of the organism, and the effect of bacteriophage in interfering with proper fermentation. Among the more significant results were the selection of efficient strains of $B$. polymyxa (capable of giving yields of over 3 percent), the finding that low-grade was as satisfactory as high-grade wheat for use in the fermentation mash, and the establishing of the nitrogen, mineral and vitamin requirements for most effective growth of the organism (36).

A study of the effect of various bacteriophages showed them capable of suppressing fermentation by susceptible strains of $B$. polymyxa; however, certain resistant cultures gave good yields in the presence of phage. Since some of the strains were lysogenic, it was considered that for best factory conditions, precautions should be taken to ensure proper sterilization of equipment, aseptic technique, and the use of effective, nonlysogenic strains (37).

\section{Antibiotics}

In a study of the production of antibiotics by Fungi Imperfecti, a species of Aspergillus was found that proved to be an active producer of citrinin, a substance which inhibits Gram-positive bacteria. Chief attention was directed to studying the effect of environmental conditions, including nutrition of the organism, on the production of citrinin, on methods of recovery and crystallization from the culture fluids and on its action against a range of bacteria. Under optimum conditions yields as high as 4.2 grams per liter were obtained (108).

Two species of Penicillium isolated from soil were found to synthesize the antibiotic claviformin (clavacin, patulin) active against most Gram-negative and Gram-positive bacteria. Optimum conditions for production, extraction, and crystallization of the antibiotic were established, about 1.0 gram per liter being obtained (73). Since the toxic properties of the antibiotic precluded its use for animal injection, studies were made on its possible application for treating seed to 
destroy loose smut, Ustilago tritici. Though found to be highly fungicidal in vitro against mycelium and chlamydospores, when tested with smutted wheat seed it failed to prevent the plants from developing smut (106).

In cooperation with the Forest Products Laboratory, Department of Mines and Resources, tests were made on the practicability of using sulphite waste liquor, a by-product of the pulp and paper industry, as a medium for the production of penicillin. In spite of modifications of the liquor to favor development of Penicillium notatum, the low yields obtained suggested that this by-product was not suitable for commercial penicillin production (72).

\section{Vitamins}

Increasing recognition of the role played in animal nutrition by vitamin $B_{12}$, first obtained in crystalline form in 1948, suggested studies on the capabilities of microorganisms for synthesis of this growth factor. A survey of 676 cultures of actinomycetes from soil, and of 537 strains of bacteria from soil, seed, and other sources demonstrated a widespread capacity for synthesis of the vitamin, 67 percent of the former and 65 percent of the latter being capable of producing varying amounts. Species of Nocardia from soil proved capable of giving highest yields (4). In a special study of different species of Rhizobium, the symbiotic nitrogen-fixing organism, a surprising relationship of vitamin $\mathrm{B}_{12}$-synthesizing capacity to the species was noted in this closely related group. Rhizobium meliloti, the alfalfa root nodule organism, was sharply distinguished from the other species by its ability to produce significantly greater amounts of the vitamin (6).

\section{Disinfectants}

Disinfectants were studied extensively by the Division during the period under review. The work included fundamental work on the action of various types of germicidal compounds on bacteria, particularly those suitable for use in dairying and in the food industries, as well as experiments aimed at determining their efficacy when applied practically as sanitizing agents. Chief attention was given to the chlorine disinfectants, chiefly the hypochlorites and chloramine-T, and to the later developed quaternary ammonium compounds.

In view of the obvious application of chlorine disinfectants to dairy practice, the earlier studies dealt with their action on bacteria that commonly occur in milk and that contaminate utensils and equipment. Hypochlorites were found to be more effective than chloramine-T compounds. The work led to an extensive evaluation of the germicidal 
potency of these two types of compounds $(20,21)$. A new 'glass slide method' for evaluating disinfectants, developed in the course of the work, proved of value in assessing their germicidal effectiveness and provided information on their efficacy under practical conditions not given by other procedures. It was found that the influence of $\mathrm{pH}$ of hypochlorites was greater than that of the concentration of available chlorine in affecting germicidal potency, which was impaired by increasing alkalinity. Though chloramine-T possessed greater stability than did hypochlorite, its germicidal action was much slower and varied with the degree of alkalinity prevailing. Quaternary ammonium compounds showed greater effectiveness against Gram-positive bacteria than did hypochlorites, while the reverse held in the case of Gram-negative species (23). The more recently developed 'iodophors,' germicides in which iodine is loosely combined with nonionic wetting agents and acids, generally phosphoric, proved to be effective germicides in preliminary experiments, showing to advantage in the presence of organic matter (25).

Bacterial death-rate studies on quaternary ammonium compounds showed survival curves to be sigmoid, owing to difference in resistance of individual cells, but an exponential rate occurred when a more resistant strain was selected from survivors of disinfection (7). Further work on resistance with Serratia marcescens showed that this organism, normally suppressed by 100 parts per million, could be adapted to grow in 100,000 ppm alkyldimethylbenzyl ammonium chloride. Evidence from cytological and biochemical tests led to the hypothesis that the acquired resistance should be ascribed to an increased lipid content of the cell (8). In studies on the effect on the cells of Bacillus megaterium, when killed by this disinfectant, three significant changes were demonstrated: degeneration of the cytoplasmic membrane, extrusion of the cytoplasm, and a deterioration of strength and rigidity of the cell wall (9).

\section{New Species of Microorganisms}

During the period 1923 to 1955 many new species of bacteria and some species of yeasts and fungi were isolated and given special taxonomic study. Because of the special characteristics possessed by a number of these organisms, names were given to eleven of these species, providing a formal introduction into microbiological literature. They are listed in chronological order.

Zygosaccharomyces nussbaumeri (osmophilic yeast from honey)Lochhead and Heron, 1929.

Zygosaccharomyces richteri (osmophilic yeast from honey)-Lochhead and Heron, 1929. 
Serratia cutirubra (halophile, causing reddening of salted hides) -Lochhead, 1934.

Pseudomonas nigrifaciens (causing discoloration of butter)-White, 1940.

Spicularia terrestris (fungus from alfalfa rhizosphere)-Timonin, 1940.

Zygosaccharomyces rugosus (osmophilic yeast from honey)-Lochhead and Farrell, 1942.

Zygosaccharomyces nectarophilus (osmophilic yeast from floral nectar) —Lochhead and Farrell, 1942.

Bacillus pulvifaciens (from powdery scale of honeybee larvae) -Katznelson, 1950.

Arthrobacter terregens (from soil, requiring terregens factor)-Lochhead and Burton, 1953.

Arthrobacter pascens (from soil, synthesizing terregens factor) -Lochhead and Burton, 1953.

Bacillus apiarius (from honeybee larvae)—Katznelson, 1955. 


\section{REFERENCES}

1. Albright, W. D. Reports of Superintendent, Dominion Experimental Substation, Beaverlodge, Alberta, 1929 to 1936.

2. Bowen, J. F., Strachan, C. C.. and Moyls, A. W. Further studies of butyric fermentation in canned tomatoes. Food Technol. 8: 471-473. 1954.

3. Burton, M. O. Comparison of coliform and enterococcus organisms as indices of pollution in frozen foods. Food Research, 14: 434-438. 1949.

4. Burton, M. O., and Lochhead, A. G. Studies on the production of vitamin

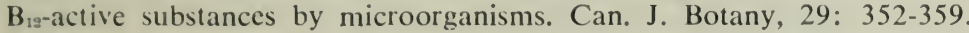
1951.

5. Burton, M. O., and Lochhead, A. G. Production of vitamin $B_{12}$ by Rhizobium species. Can. J. Botany, 30: 521-524. 1952.

6. Burton, M. O., Sowden, F. J., and Lochhead, A. G. Studies on the isolation and nature of the 'terregens factor'. Can. J. Biochem. Physiol. 32: 400-406. 1954.

7. Chaplin, C. E. Observations on quaternary ammonium disinfectants. Can. J. Botany, 29: 373-382. 1951.

8. Chaplin, C. E. Bacterial resistance to quaternary ammonium disinfectants. J. Bacteriol. 63: 453-458. 1952.

9. Chaplin, C. E. Cytological changes in Bacillus species in stasis and death caused by quaternary ammonium compounds. J. Bacteriol. 64: 805810. 1952

10. Chinn, S. H. F. A slide technique for the study of fungi and actinomycetes in soil with special reference to Helminthosporium sativum. Can. J. Botany, 31: 718-724. 1953.

11. Chinn, S. H. F., Ledingham, R. J., Sallans, B. J., and Simmonds, P. M. A mechanism for the control of common root rot of wheat. Phytopathology, 43: 701. 1953.

12. Garrard, E. H., and Lochhead, A. G. A study of bacteria contaminating sides for Wiltshire bacon with special consideration of their behaviour in concentrated salt solutions. Can. J. Research, D, 17: 45-58. 1939.

13. Hildebrand, A. A., and West, P. M. Strawberry root rot in relation to microbiological changes induced in root rot soil by the incorporation of certain cover crops. Can. J. Research, C, 19: 183-198. 1941.

14. Hlynka, I., Hood, E. G., and Gibson, C. A. Agitation and temperature of cheese milk and the development of rancid and unclean flavors in Cheddar cheese. J. Dairy Sci. 26: 1111-1119. 1943.

15. Hlynka, I., Hood, E. G., and Gibson, C. A. The degree of fat dispersion in cheese milk and its relation to the mechanism of increased lipase action in agitated milk. J. Dairy Sci. 28: 79-83. 1945.

16. Hood, E. G., and Bowen, J. F. A new type of bacterial spoilage in Canadian process cheese. Sci. Agr. 30: 38-42. 1950.

17. Hood, E. G., Gibson, C. A., and Smith, K. N. Rind rot or wet end in Canadian Cheddar cheese. Can. Dairy and Icc Cream J. 29: 60-68, 78. 1950.

18. Hood, E. G., and Smith, K. N. Bacterial spoilage in process cheese. Sci. Agr. 31: 530-540. 1951 . 
19. Johns, C. K. A simplified method for cleaning milking machine rubber parts. Sci. Agr. 13: 460-465. 1932.

20. Johns, C. K. The evaluation of the germicidal potency of chlorine compounds. I. Hypochlorides. Sci. Agr. 14: 585-607. 1934.

21. Johns, C. K. The evaluation of the germicidal potency of chlorine compounds. II. Chloramine-T products. Sci. Agr. 15: 218-227. 1934.

22. Johns, C. K. Microbiological aspects of egg powder. Sci. Agr. 24: 373-382. 1944.

23. Johns, C. K. Studies comparing the sanitizing efficiencies of hypochlorites and quaternary ammonium compounds. Can. J. Research, F, 25: 76-91. 1947.

24. Johns, C. K. Differences in sensitivity of lactic starters to antibiotics. J. Dairy Sci. 36: 1241-1247. 1953.

25. Johns, C. K. Iodophors as sanitizing agents. Can. J. Technol. 32: 71-77. 1954.

26. Johns, C. K., and Bérard, H. L. Direct microscopic method in bacteriological control of dried whole eggs. Food Research, 9: 396-399. 1944.

27. Johns, C. K., and Bérard, H. L. The effect of freezing and cold storage upon the bacterial content of egg melange. Sci. Agr. 26: 34-42. 1946.

28. Johns, C. K., and Desmarais, J. G. The Burri slant method in the bacteriological control of frozen egg. Food Technol. 5: 36-37. 1951.

29. Johns, C. K., and Hastings, E. G. Concerning the use of indirect biochemical tests for the diagnosis of chronic contagious mastitis. Can. J. Research, D, 16: 6-14. 1938.

30. Johns, C. K., Hicks, T. J., and Gibson, C. A. The influence of "mastitis" upon the yield and quality of Cheddar cheese. J. Dairy Research, 11: 298-304. 1940.

31. Johns, C. K., and Howson, R. K. A modified resazurin test for the more accurate estimation of milk quality. J. Milk Technol. 3: 320.1940.

32. Johns, C. K., and Katznelson, H. Studies on bacteriophage in relation to Cheddar cheesemaking. Can. J. Research, C, 19: 49-58. 1941.

33. Jones, A. H. A study of organisms causing gaseous spoilage of canned tomato products. Can. Canner and Food Manufacturer, 7: 9-14. 1936.

34. Jones, A. H. Microbiological aspects of dehydrated vegetables and fruits. Food in Canada, 3: 16-18, 20-23. 1943.

35. Jones, A. H., and Lochhead, A. G. A study of micrococci surviving in frozen-pack vegetables and their enterotoxic properties. Food Research, 4: 203-216. 1939.

36. Katznelson, H. Studies with Bacillus polymyxa. I. Some factors affecting the fermentation of wheat by Bacillus polymyxa. Can. J. Research, C, 22: 235-240. 1944.

37. Katznelson, H. Studies with Bacillus polymyxa. II. Bacteriophage of Bacillus polymyxa in relation to the 2,3-butanediol fermentation. Can. J. Research, C, 22: 241-250. 1944.

38. Katznelson, H. The 'rhizosphere effect' of mangels on certain groups of soil microorganisms. Soil Sci. 62: 343-354. 1946.

39. Katznelson, H. Sulfathiazole in relation to American foulbrood. Sci. Agr. 29: 340-344. 1949. 
40. Katznelson. H. The influence of antibiotics and sulfa drugs on Bacillus larvac, cause of American foulbrood of the honeybee, in vitro and in vivo. J. Bacteriol. 59: 471-479. 1950.

41. Katznelson. H., Arnott, J. H., and Bland, S. E. Preliminary report on the treatment of European foulbrood of honeybees with antibiotics. Sci. Agr. 32: 180-184. 1952.

42. Katznelson. H., and Hood, E. G. Influence of penicillin and other antibiotics on lactic streptococci in starter cultures used in Cheddar cheesemaking. J. Dairy Sci. 32: 961-968. 1949.

43. Katznelson, H., and Jamieson, C. A. Antibiotics and other chemotherapeutic agents in the control of bee diseases. Sci. Agr. 32: 219-225. 1952.

44. Katznelson, H.. Jamieson, C. A., and Austin, G. H. Further studies on the chemotherapy of diseases of the honeybee. Can. J. Agr. Sci. 35: 189-192. 1955.

45. Katznelson, H., Jamieson, C. A., Lawton, E. J., and Bellamy, W. D. Studies on the treatment of contaminated combs and honey with high velocity electrons. Can. J. Technol. 30: 95-103. 1952.

46. Katznelson. H. and Lochhead, A. G. Notes on the longevity, sporulation and diagnosis of Bacillus larvae, the cause of American foulbrood of bees. Sci. Agr. 24: 474-480. 1944.

47. Katznelson, H., and Lochhead, A. G. Rapid field tests for the diagnosis of American foulbrood of bees. Sci. Agr. 27: 67-71. 1947.

48. Katznelson, H., and Lochhead, A. G. Nutritional requirements of Bacillus alvei and Bacillus para-alvei. J. Bacteriol. 53: 83-88. 1947.

49. Katznelson, H., and Lochhead, A. G. Growth factor requirements of halophilic bacteria. J. Bacteriol. 64: 97-103. 1952.

50. Katznelson, H., and Richardson, L. T. The microflora of the rhizosphere of tomato plants in relation to soil sterilization. Can. J. Research, C, 21: 249-255. 1943.

51. Katznelson, H., and Richardson, L. T. Rhizosphere studies and associated microbiological phenomena in relation to strawberry root rot. Sci. Agr. 28: 293-308. 1948.

52. Katznelson, H., Rouatt, J. W., and Payne, T. M. B. The liberation of amino acids and reducing compounds by plant roots. Plant and Soil, 7: $35-48.1955$.

53. Katznelson, H., and Sutton, M. D. A rapid phage plaque count method for the detection of bacteria as applied to the demonstration of internally borne bacterial infections of seed. J. Bacteriol. 61: 689701. 1951.

54. Katznelson, H., Sutton, M. D., and Bayley, S. T. The use of bacteriophage of Xanthomonas phaseoli in detecting infection in beans, with observations on its growth and morphology. Can. J. Microbiol. 1: 22-29. 1954.

55. Katznelson, H., and White, A. H. Nutritional requirements of Pseudomomonas nigrifaciens as related to growth and pigment production. Can. J. Research, C, 28: 706-715. 1950.

56. Landerkin, G. B. Studies on the bacteriology of Wiltshire bacon: Methods for quantitative analysis of curing pickle. Food Research, 5: 205-214. 1940. 
57. Landerkin, G. B., Smith, J. R. G., and Lochhead, A. G. A study of the antibiotic activity of actinomycetes from soils of Northern Canada. Can. J. Research, C, 28: 690-698. 1950.

58. Lochhead, A. G. Microbiological studies of frozen soil. Trans. Roy. Soc. Canada, Ser. 3, 18: 75-96. 1924.

59. Lochhead, A. G. The bacterial types occurring in frozen soil. Soil Sci. 21: 225-231. 1926.

60. Lochhead, A. G. Producing clean milk. Can. Dep. Agr. Pamphlet No. 79(N.S.). 1927.

61. Lochhead, A. G. The longevity of legume bacteria on inoculated alfalfa seed. Sci. Agr. 7: 179-184. 1927.

62. Lochhead, A. G. Cultural studies of Bacillus larvae White. Sci. Agr. 9: 80-89. 1928.

63. Lochhead, A. G. Studies on the etiology of European foulbrood of bees. Proc. IV Int. Congr. Entomol. 2: 1005-1009. 1929.

64. Lochhead, A. G. Reports of the Dominion Agricultural Bacteriologist for 1925 and 1929-30.

65. Lochhead, A. G. Factors concerned with the fermentation of honey. Zentralbl. f. Bakt. Abt. II, 88: 296-302. 1933.

66. Lochhead, A. G. Bacteriological studies on the red discoloration of salted hides. Can. J. Research, 10: 275-286. 1934.

67. Lochhead, A. G. Qualitative studies of soil microorganisms. III. Influence of plant growth on the character of the bacterial flora. Can. J. Research, C, 18: 42-53. 1940.

68. Lochhead, A. G. Growth factor requirements of Bacillus larvae White. J. Bacteriol. 44: 185-189. 1942.

69. Lochhead, A. G., and Burton, M. O. An essential bacterial growth factor produced by microbial synthesis. Can. J. Botany, 31: 7-22. 1953.

70. Lochhead, A. G., and Burton, M. O. Qualitative studies of soil microorganisms. XII. Characteristics of vitamin $\mathbf{B}_{12}$ requiring bacteria. Can. J. Microbiol. 1: 319-330. 1955.

71. Lochhead, A. G., and Chase, F. E. Qualitative studies of soil microorganisms. V. Nutritional requirements of the predominant bacterial flora. Soil Sci. 55: 185-195. 1943.

72. Lochhead, A. G., and Chase, F. E. Production of antibacterial substances from sulphite waste liquor by Penicillium notatum. Can. J. Research, F, 23: 161-167. 1945.

73. Lochhead, A. G., Chase, F. E., and Landerkin, G. B. Production of claviformin by soil penicillia. Can. J. Research, E, 24: 1-9. 1946.

74. Lochhead, A. G., and Farrell, L. Soil as a source of infection of honey by sugar-tolerant yeasts. Can. J. Research, 3: 51-64. 1930.

75. Lochhead, A. G., and Farrell, L. Accessory food substances for osmophilic yeasts. I. A bioactivator in honey stimulating fermentation. Can. J. Research, 5: 529-538. 1931.

76. Lochhead, A. G., and Heron, D. A. Microbiological studies of honey. Dom. of Can. Dep. Agr. Bull. 116, (N.S.) 1929.

77. Lochhead, A. G., and Johns, C. K. Bacteriological investigations of milking machines. Can. Dep. Agr. Bull. No. 127 (N.S.). 1929. 
78. Lochhead, A. G., and Jones, A. H. Studies of numbers and types of microorganisms in frozen vegetables and fruits. Food Research, 1: 29-39. 1936.

79. Lochhead, A. G., and Jones, A. H. Types of bacteria surviving in frozenpack vegetables. Food Research, 3: 299-306. 1938.

s(). Lochhead, A. G., and Landerkin, G. B. Bacteriological studies of dressed poultry. Sci. Agr. 15: 765-770. 1935.

81. Lochhead, A. G., and Landerkin. G. B. Nutrilite requirements of osmophilic yeasts. J. Bacteriol. 44: 343-351. 1942.

82. Lochhead, A. G., and Landerkin, G. B. Aspects of antagonisms between microorganisms in soil. Plant and Soil, 1: 271-276. 1949.

83. Lochhead, A. G.. and McMaster, N. B. Yeast infection of normal honey and its relation to fermentation. Sci. Agr. 11: 351-360. 1931.

84. Lochhead. A. G., and Rouatt, J. W. The 'rhizosphere effect' on the nutritional groups of soil bacteria. Soil Sci. Soc. Amer. Proc. 19: 48-49. 1955.

85. I.ochhead. A. G., and Taylor, C. B. Qualitative studies of soil microorganisms. I. General introduction. Can. J. Research, C, 16: 152-161. 1938.

86. Lochhead, A. G., and Thexton, R. H. A four-year quantitative study of nitrogen-fixing bacteria in soils of different fertilizer treatment. Can. J. Research, C, 14: 166-177. 1936.

87. Lochhead, A. G., and Thexton, R. H. Qualitative studies of soil microorganisms. VII. The 'rhizosphere effect' in relation to the amino acid nutrition of bacteria. Can. J. Research, C, 25: 20-26. 1947.

88. Lochhead, A. G., and Thexton, R. H. Vitamin $B_{12}$ as a growth factor for soil bacteria. Nature, 167: 1034. 1951.

89. Peterson, E. A. A study of cross antagonisms among some actinomycetes active against Streptomyces scabies and Helminthosporium sativum. Antibiotics and Chemotherapy, 4: 145-149. 1953.

90. Peterson, E. A., and Katznelson, H. Studies on the nutrition of Helminthosporium sativım and certain related species. Can. J. Microbiol. 1: 190-197. 1954.

91. Robinson. J., and Katznelson, H. Aspartate-glutamate transaminase in a red halophilic bacterium. Nature, 172: 672. 1953.

92. Rouatt, J. W., and Atkinson, R. G. The effect of the incorporation of certain cover crops on the microbiological balance of potato scab infested soil. Can. J. Research, C, 28: 140-152. 1950.

93. Rouatt, J. W., and Lochhead, A. G. Qualitative studies of soil microorganisms. XIII. Effect of decomposition of various crop plants on the nutritional groups of soil bacteria. Soil Sci. 80: 147-154. 1955.

94. Stacey, E. C. Field studies of alfalfa inoculation. Sci. Agr. 18: 277-282. 1938.

95. Stevenson, I. L. Microbiological examination of soils of Arno Atoll. Soil Sci. 75: 225-231. 1953.

96. Stevenson, I. L. Antibiotic production by actinomycetes in soil demonstrated by morphological changes induced in Helminthosporium sativum. Nature, 174: 598. 1954.

97. Stevenson, I. L., and Lochhead, A. G. The use of a percolation technique in studying antibiotic production in soil. Can. J. Botany, 31: 23-27. 1953. 
98. Sutton, M. D., and Katznelson, H. Isolation of bacteriophages for the detection and identification of some seed-borne pathogenic bacteria. Can. J. Botany, 31: 201-205. 1953.

99. Taylor, C. B. Further studies of Bacterium globiforme and the incidence of this type of organism in Canadian soils. Soil Sci. 46: 307-321. 1938.

100. Taylor, C. B., and Lochhead, A. G. A study of Bacterium globiforme Conn in soils differing in fertility. Can. J. Research, C, 15: 340-347. 1937.

101. Taylor, C. B., and Lochhead, A. G. Qualitative studies of soil microorganisms. II. A survey of the bacterial flora of soils differing in fertility. Can. J. Research, C, 16: 162-173. 1938.

102. Timonin, M. I. The interaction of higher plants and soil microorganisms. I. Microbial population of rhizosphere of seedlings of certain cultivated plants. Can. J. Research, C, 18: 307-317. 1940.

103. Timonin, M. I. The interaction of higher plants and soil microorganisms. II. Study of the microbial population of the rhizosphere in relation to resistance of plants to soil-borne diseases. Can. J. Research, B, 18: 444-456. 1940.

104. Timonin, M. I. The interaction of higher plants and soil microorganisms. III. Effect of by-products of plant growth on activity of fungi and actinomycetes. Soil Sci. 52: 395-413. 1941.

105. Timonin, M. I. Microflora of the rhizosphere in relation to the manganese deficiency disease of oats. Soil Sci. Soc. Amer. Proc. 11: 284-292. 1946.

106. Timonin, M. I. Activity of patulin against Ustilago Tritici (Pers.) Jen. Sci. Agr. 26: 358-368. 1946.

107. Timonin, M. I. Azotobacter preparation as a fertilizer for cultivated plants. Soil Sci. Soc. Amer. Proc. 13: 246-250. 1948.

108. Timonin, M. I., and Rouatt, J. W. Production of citrinin by Aspergillus sp. of the Candidus group. Can. J. Pub. Health, 35: 80-88. 1944.

109. Wallace, R. H., and Lochhead, A. G. Qualitative studies of soil microorganisms. VIII. Influence of various crop plants on the nutritional groups of soil bacteria. Soil Sci. 67: 63-69. 1949.

110. Wallace, R. H., and Lochhead, A. G. Bacteria associated with the seed of various crop plants. Soil Sci. 71: 159-166. 1951.

111. West, P. M., and Hildebrand, A. A. The microbiological balance of strawberry root rot soil as related to the rhizosphere and decomposition effects of certain cover crops. Can. J. Research, C, 19: 199-210. 1941.

112. West, P. M., and Lochhead, A. G. Qualitative studies of soil microorganisms. IV. The rhizosphere in relation to the nutritive requirements of soil bacteria. Can. J. Research, C, 18: 129-135. 1940.

113. West, P. M., and Lochhead, A. G. The nutritional requirements of soil bacteria-a basis for determining the bacterial equilibrium of soils. Soil Sci. 50: 409-420. 1940.

114. White, A. H. A bacterial discoloration of print butter. Sci. Agr. 20: 638-645. 1940. 
115. White, A. H. Studies of storage butters showing surface deterioration. Sci. Agr. 23: 41-58. 1942.

116. Wolochow, H., Thornton, H. R., Hood, E. G., and McCallum, D. H. The cause and control of surface taint butter. Bulletin, reprinted from the Canadian Dairy and Ice Cream J. Oct., Nov. 1942. 


\section{ACKNOWLEDGMENTS}

For the opportunity offered by the Research Branch of the Department of Agriculture to record some of the history of the Bacteriology Division during my term as Chief from 1923 to 1955, I am most grateful.

I want to express my deep appreciation of the support and encouragement so generously given by the Directors of the Experimental Farms Service and Science Service under whom I have been privileged to serve, Dr. E. S. Archibald, the late Dr. J. M. Swaine, and the late Dr. K. W. Neatby. I further acknowledge my indebtedness to the former Chiefs of the various Divisions of the Department and the Branch Experimental Farm Superintendents for their willing cooperation in many projects, and especially to my associates in the Bacteriology Division; working with them throughout the years has been a pleasant and rewarding experience.

Thanks are due to the late Dr. H. Katznelson, Director of the Microbiology Research Institute, and to Dr. C. K. Johns, previously Director of the Dairy Technology Research Institute, both former colleagues, for making records and material available. I am also much indebted to Miss E. M. Finn who aided in many ways, not the least of which was by helping me recall the sequence of many events. 


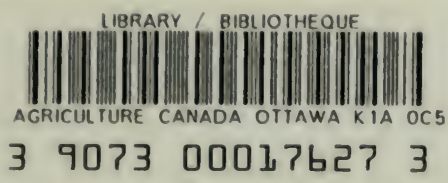

\section{DATE DUE} DATE DE RETOUR

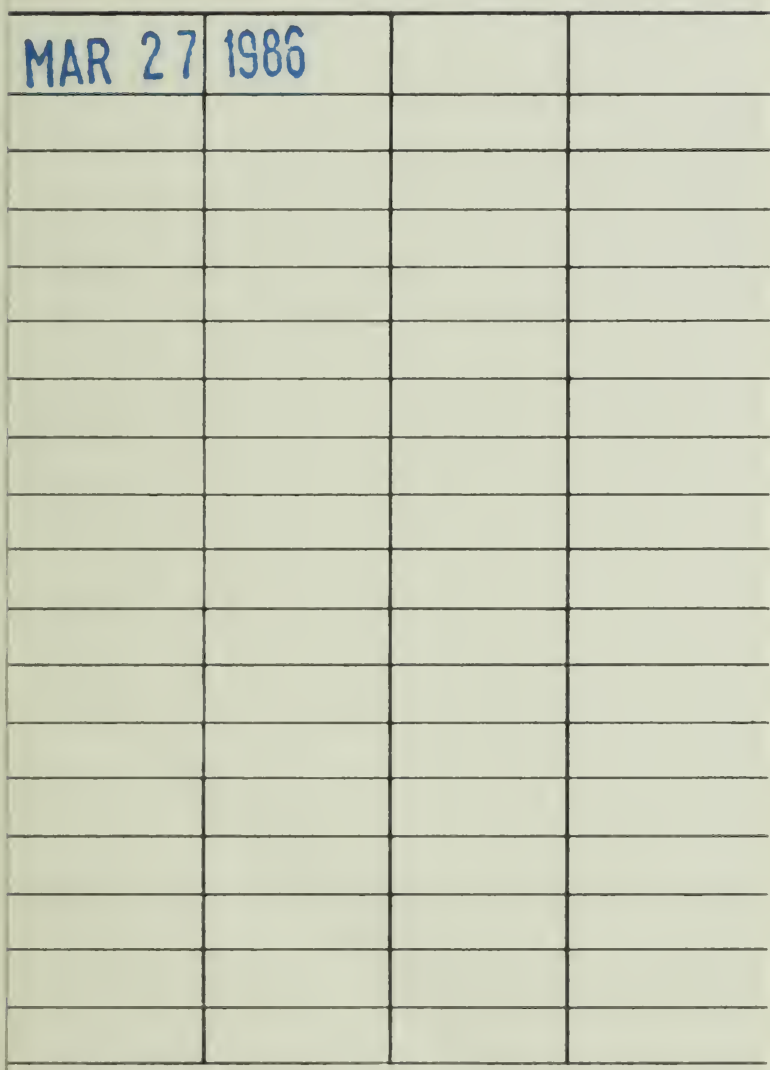

LOWE-MARTIN No. 1137 
